\title{
A multi-scale risk assessment for tephra fallout and airborne concentration from multiple Icelandic volcanoes - Part 2: Vulnerability and impact
}

\author{
C. Scaini ${ }^{1}$, S. Biass ${ }^{2}$, A. Galderisi ${ }^{3}$, C. Bonadonna ${ }^{2}$, A. Folch ${ }^{1}$, K. Smith ${ }^{4}$, and A. Höskuldsson ${ }^{5}$ \\ ${ }^{1}$ CASE Department, Barcelona Supercomputing Center (BSC-CNS), Barcelona, Spain \\ ${ }^{2}$ Section of Earth and Environmental Sciences, University of Geneva, Geneva, Switzerland \\ ${ }^{3}$ Department of Civil, Architectural and Environmental Engineering (DICEA) - University Federico II of Naples, \\ Naples, Italy \\ ${ }^{4}$ Geography, College of Life and Environmental Science, University of Exeter, Cornwall Campus, Penryn, UK \\ ${ }^{5}$ Nordic Volcanological Center, University of Iceland, Reykjavík, Iceland
}

Correspondence to: C. Scaini (saetachiara@gmail.com) and S. Biass (sebastien.biasse@unige.ch)

Received: 2 March 2014 - Published in Nat. Hazards Earth Syst. Sci. Discuss.: 9 April 2014

Revised: 21 July 2014 - Accepted: 25 July 2014 - Published: 29 August 2014

\begin{abstract}
We perform a multi-scale impact assessment of tephra fallout and dispersal from explosive volcanic activity in Iceland. A companion paper (Biass et al., 2014; "A multiscale risk assessment of tephra fallout and airborne concentration from multiple Icelandic volcanoes - Part I: hazard assessment") introduces a multi-scale probabilistic assessment of tephra hazard based on selected eruptive scenarios at four Icelandic volcanoes (Hekla, Askja, Eyjafjallajökull and Katla) and presents probabilistic hazard maps for tephra accumulation in Iceland and tephra dispersal across Europe. Here, we present the associated vulnerability and impact assessment that describes the importance of single features at national and European levels and considers several vulnerability indicators for tephra dispersal and deposition. At the national scale, we focus on physical, systemic and economic vulnerability of Iceland to tephra fallout, whereas at the European scale we focus on the systemic vulnerability of the air traffic system to tephra dispersal. This is the first vulnerability and impact assessment analysis of this type and, although it does not include all the aspects of physical and systemic vulnerability, it allows for identifying areas on which further specific analysis should be performed. Results include vulnerability maps for Iceland and European airspace and allow for the qualitative identification of the impacts at both scales in the case of an eruption occurring. Maps produced at the national scale show that tephra accumulation associated with all
\end{abstract}

eruptive scenarios considered can disrupt the main electricity network, in particular in relation to an eruption of Askja. Results also show that several power plants would be affected if an eruption occurred at Hekla, Askja or Katla, causing a substantial systemic impact due to their importance for the Icelandic economy. Moreover, the Askja and Katla eruptive scenarios considered could have substantial impacts on agricultural activities (crops and pastures). At the European scale, eruptive scenarios at Askja and Katla are likely to affect European airspace, having substantial impacts, in particular, in the Keflavík and London flight information regions (FIRs), but also at FIRs above France, Germany and Scandinavia. Impacts would be particularly intense in the case of longlasting activity at Katla. The occurrence of eruptive scenarios at Hekla is likely to produce high impacts at Keflavík FIR and London FIRs, and, in the case of higher magnitude, can also impact France's FIRs. Results could support land use and emergency planning at the national level and risk management strategies of the European air traffic system. Although we focus on Iceland, the proposed methodology could be applied to other active volcanic areas, enhancing the longterm tephra risk management. Moreover, the outcomes of this work pose the basis for quantitative analyses of expected impacts and their integration in a multi-risk framework. 


\section{Introduction}

Tephra dispersal and deposition during explosive volcanic eruptions can produce impacts at different scales, from local to continental. Compared to other volcanic hazards, tephra fallout is unlikely to cause casualties, but, nonetheless, it often produces high systemic and socioeconomic impacts (e.g., Wardman et al., 2012; Biass et al., 2012). Moreover, the presence of volcanic ash in the atmosphere disrupts aerial navigation and may produce additional socioeconomic impacts at larger scales, from regional to continental, depending on the eruption intensity and duration, ash properties and atmospheric circulation. For these reasons a comprehensive risk assessment of active explosive volcanoes that are located in areas with high population and flight density should always include the hazard associated with both tephra dispersal and accumulation. Iceland is amongst the most active volcanic areas in the world, hosting more than 30 volcanic systems that display different eruptive styles and a wide range of volcanic products (Thordarson and Larsen, 2006). In a companion paper, Biass et al. (2014) present a probabilistic tephra hazard assessment from four Icelandic volcanoes (Hekla, Askja, Katla and Eyjafjallajökull) selected for showing recent activity, different levels of historical record, and a variety of eruptive styles and activities. In this manuscript we present the associated vulnerability and impact assessment in order to support more effective mitigation strategies in Iceland and Europe. As for other natural risks, volcanic risk evaluation builds upon three factors: hazard, exposure and vulnerability (e.g., De la Cruz Reyna and Tilling, 2008). Exposure is a key element in risk assessment, since it "encompasses all elements, processes, and subjects that might be affected by a hazardous event. Consequently, exposure is the presence of social, economic, environmental or cultural assets in areas that may be impacted by a hazard" (Birkmann, 2013, p. 305). Thus, the identification of exposed targets largely depends on their location with respect to the impacted area for the considered hazard and to the type of hazard at stake. Finally, the exposure, although crucial for an effective risk assessment, does not account for the variability of response of people, infrastructure, goods or ecosystems to the hazardous event: such response depends on their susceptibility to be harmed or, in other words, on their vulnerability. Vulnerability can be defined as the potential of exposed targets to be directly or indirectly damaged by a given hazard. Definitions, conceptual frameworks and methodologies for analyzing and assessing vulnerability are very heterogeneous, although "there is a clear recognition of the importance of place-based studies in examining vulnerability" (Cutter, 2013, p. 1089). In the last decade, vulnerability has been largely recognized as a multidimensional concept, comprising different aspects (physical, systemic, social, economic, environmental, institutional, etc.) constantly interacting in time and space (Birkmann, 2006; Galderisi et al., 2008; UNISDR, 2009; Menoni et al., 2011). In particular, the concept of systemic vulnerability is becoming more widespread in the scientific literature and refers to the fragilities arising as a consequence of interdependencies among elements and systems within a given territory, which can reduce its overall functioning in the face of a hazardous event (Rashed and Weeks, 2003; Menoni, 2005; Galderisi et al., 2008; Pascale et al., 2010; Ensure, 2011). Territorial systems are characterized by a dense network of physical and functional interdependencies (Paton and Johnston, 2006; Hellstrom, 2007), and the potential impact of a hazard on a given element may reverberate on to others that are physically or functionally connected to the former. The concept of systemic vulnerability has been applied in several areas of natural hazards such as floods, earthquakes, tsunamis, etc. (e.g., Minciardi et al., 2005; Pascale et al., 2010), but in volcanology this concept has been introduced only recently (e.g., Galderisi et al., 2013). Systemic vulnerability has a particular relevance in the case of tephra fallout, which may produce much higher secondary than primary impacts; that is, the physical failure of an element may also impact other connected activities and infrastructures (Biass et al., 2012). For example, the failure of the electrical network can cause cascading effects on several productive activities, such as manufacturing, power generation, agriculture or tourism. Furthermore, tephra dispersal and deposition largely affect transportation networks, which are crucial for accessibility to urban areas and emergency facilities. Finally, social and economic aspects of vulnerability have been deepened in scientific literature since the 1990s, but an unequivocal definition of both social and economic vulnerabilities and of their mutual relationships is still missing (Parker and Tapsell, 2009; Tapsell et al., 2010). The aim of this analysis is performing a vulnerability and impact assessment analysis at national and European levels. Due to the large scale of the analysis and the lack of specific data, physical vulnerability is not considered in our assessment, with the exception of few specific elements of particular relevance (i.e., electric power plants and distribution network). A comprehensive assessment of physical vulnerability is beyond the scope of this paper. Moreover, we consider only one aspect of the systemic vulnerability, i.e., the a priori identification of elements and systems that are particularly relevant from a systemic point of view. We do not account for the cascading effects and spatial interdependences that may take place during the emergency. Through this simplified approach, the vulnerability and impact assessment presented here aims at identifying the areas that are likely to suffer the higher impacts, where more specific research should be performed. This approach is commonly adopted in risk management for hazardous phenomena whose physical impact on elements are not yet quantified, and in particular for those which do not cause large losses of life and socioeconomic impacts (Douglas, 2007). Iceland is considered a well-prepared and highly resilient country, but the traditional risk management strategies of the Icelandic Civil Protection have traditionally focused on the short-term reaction rather than on long-term 
land use planning (Jóhannesdóttir and Gísladóttir, 2010). As a consequence, there is a lack of specific studies on vulnerability of the Icelandic territory to tephra deposition, even though tephra fallout is a relatively frequent phenomenon in Iceland. Here we perform a vulnerability assessment taking into account that, according to the analysis of past events (Biass et al., 2014), agriculture, transportation and energy sectors are the most vulnerable to tephra accumulation. We focus on systemic and economic dimensions of vulnerability. To this aim, we define exposed targets, estimate vulnerability for each considered target, and evaluate the expected impacts for all the eruptive scenarios defined in the previous hazard assessment. Physical vulnerability of buildings is not considered because, according to the hazard analysis of Biass et al. (2014), expected tephra accumulations are unlikely to cause significant damage to buildings for the volcanoes and activity scenarios considered (proximal areas around the selected volcanoes are mostly uninhabited). Moreover, our analysis is performed at a national scale (the whole island), while physical vulnerability assessments require detailed onsite surveys, for example on building stock, which are usually performed at the local scale. However, we consider physical vulnerability of the electricity network because its failure can trigger relevant impacts on the whole of society. We also focus on the potential for temporary or permanent loss of economic activities, which is relevant to the maintenance of the level of welfare of the population. The disruption of flights caused by the 2010 Eyjafjallajökull event was economically significant for both Europe and Iceland (Sammonds et al., 2010; Oxford Economics, 2010; Alexander, 2013). Using the last 10 years of the ERA-Interim reanalysis data set, Biass et al. (2014) conclude that the probability of having uppertroposphere winds blowing towards central and northern Europe is $6-8 \%$, a value consistent with the $6 \%$ found by Sammonds et al. (2010). Given the experience from 2010, these probabilities suggest that assessing the vulnerability of the European air traffic system to Icelandic ash dispersal is relevant for the management of volcanic risk in civil aviation, particularly since no vulnerability assessment of any air traffic system specifically focused on volcanic ash hazard exists. Wegner and Marsh (2007) and Wilkinson et al. (2001) underlined some relevant aspects of the European air traffic network and showed that it is a scale-free network highly vulnerable to the disruption of the main hubs. Based on this finding, we develop the first assessment of vulnerability of the European airspace to tephra dispersal. The analysis is based on the systemic approach and aims to identify the critical features for the system, i.e., the elements that can produce the highest systemic impacts on the whole European air traffic system in the case of failure. As we did at the national scale, we identify the distribution and the features of the exposed targets and define vulnerability indicators in order to evaluate the expected impact for the different eruptive scenarios considered in the hazard assessment.

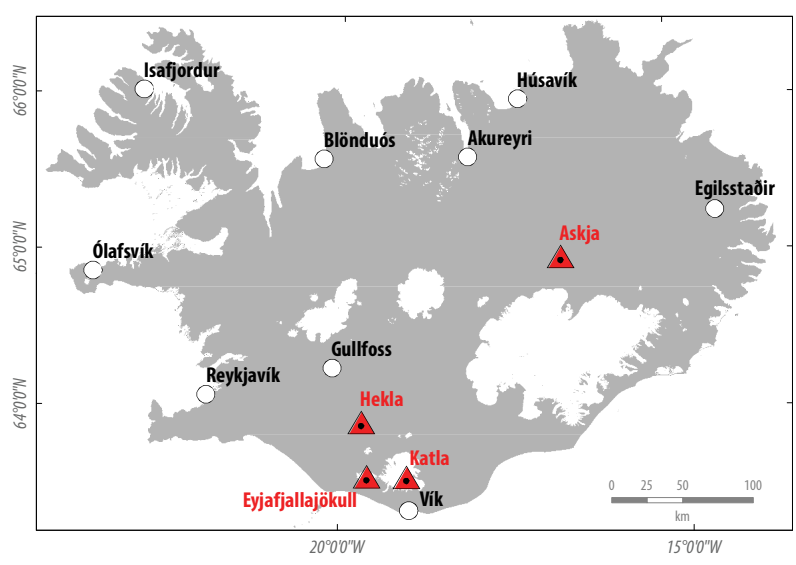

Figure 1. Map of Iceland showing the location of the four volcanoes considered in the hazard assessment and the main cities and towns. The administrative units (municipalities) used for the national vulnerability analysis are given in the Supplement.

This manuscript is arranged as follows. Section 2 overviews the eruptive scenarios for the selected volcanoes and the findings from the hazard assessment of Biass et al. (2014). Section 3 presents the vulnerability and impact assessment of tephra fallout at the national scale, and Sect. 4 presents the vulnerability and impact assessment of tephra dispersal at the European scale. Section 5 discusses the advantages and disadvantages of the proposed methodology and the future research developments required to improve it. Finally, Sect. 6 concludes the paper with a summary.

\section{Eruptive scenarios and results from the hazard assessment}

A companion paper (Biass et al., 2014) presents a multi-scale probabilistic tephra hazard assessment for different eruptive scenarios of four highly active Icelandic volcanoes (Hekla, Askja, Katla and Eyjafjallajökull; Fig. 1). These four volcanoes were selected for their high probabilities of eruption and/or their high potential impacts, and the associated hazard was assessed for dispersal at both national and European scale for different scenarios based on the eruptive record (Table 1). Scenarios are associated with a volcanic explosivity index (VEI) as described by Biass et al. (2014). Each scenario was modeled assuming a statistical set of inputs using TEPHRA (Bonadonna et al., 2005) and FALL3D (Costa et al., 2006; Folch et al., 2009) models for tephra fallout and dispersal, respectively. Results of the hazard assessment at the national scale are probabilistic hazard maps for ground tephra accumulation. Given the rich historical record and high knowledge of Icelandic volcanic activity, it is possible with some volcanoes (e.g., Hekla) to associate scenarios with a "repose time", while other volcanoes have a short documented eruptive history or do not seem to follow evolution 
Table 1. Synthesis of the eruptive scenarios considered in the tephra hazard assessment (Biass et al., 2014). ERS: eruption range scenario; OES: one-eruption scenario; LLERS: long-lasting eruption range scenario; LLOES: long-lasting one-eruption scenario. Tephra accumulation and dispersal was assessed for Hekla, Askja and Katla, while for Eyjafjallajökull only tephra accumulation was modeled (Biass et al., 2014).

\begin{tabular}{lllccc}
\hline Volcano & $\begin{array}{l}\text { Modeling } \\
\text { strategy }\end{array}$ & $\begin{array}{l}\text { Reference } \\
\text { eruption }\end{array}$ & $\begin{array}{c}\text { Column } \\
\text { height }(\mathrm{km} \text { a.s.l) }\end{array}$ & VEI & $\begin{array}{c}\text { Eruption } \\
\text { duration }\end{array}$ \\
\hline Eyjafjallajökull & LLOES & 2010 & $2.5-7.8$ & 2 & 40 days \\
Hekla & ERS & 2000 & $16.0-30.0$ & 2 & $0.5-1 \mathrm{~h}$ \\
Hekla & ERS & 1947 & $6.0-16.0$ & 3 & $0.5-1 \mathrm{~h}$ \\
Katla & LLERS & Historical moderate/large & $10.0-25.0$ & - & $1-4$ days \\
Askja & OES & $1875(\mathrm{C}+\mathrm{D}$ phases $)$ & $22.8-26.0$ & 5 & $1 \mathrm{~h}+1.5 \mathrm{~h}(\mathrm{C}+\mathrm{D}$ phases $)$ \\
\hline
\end{tabular}

patterns. Scenarios used in this work are not associated with a probability of occurrence, due to the high uncertainties of such an approach. Thus, probabilistic hazard maps represent the expected situation conditioned to the occurrence of the scenario, i.e., the probability of having critical tephra load at a given point if the considered scenario occurs. Probabilistic hazard maps were computed for tephra load thresholds of 1 , 10 and $100 \mathrm{~kg} \mathrm{~m}^{2}$, which correspond to approximately 0.1 , 1 and $10 \mathrm{~cm}$ of accumulation on the ground. At a European scale, results are probabilistic hazard maps (giving the probability of "disruption") for ash mass concentration thresholds of 2 and $2 \times 10^{-3} \mathrm{mg} \mathrm{m}^{-3}$. The second value (corresponding to a negligible mass concentration) was considered in order to estimate the impact in the case of a zero-ash-tolerance criterion. Moreover, Biass et al. (2014) provide maps of disruption mean persistence (according to Sulpizio et al., 2012) and arrival times for the $2 \mathrm{mg} \mathrm{m}^{-3}$ concentration threshold. The main findings from the hazard assessment are (scenarios and their acronyms are described in Table 1) as follows:

- A 10-year recurrence rate eruption of Hekla (i.e., Hekla ERS 2000 type) only produces significant tephra accumulation close to the vent and in the southern part of Iceland. Ash concentration has a low probability $(<1 \%)$ of exceeding the threshold of $2 \mathrm{mg} \mathrm{m}^{-3}$ at any flight level (FL) in the UK airspace.

- A 100-year recurrence rate eruption of Hekla (i.e., Hekla ERS 1947 type) produces substantial tephra accumulation in the southeastern part of Iceland. However, far-range ash concentrations still have low probabilities $(<5 \%)$ of affecting the UK airspace, with concentrations above the $2 \mathrm{mg} \mathrm{m}^{-3}$ threshold at any FL.

- A moderate long-lasting basaltic eruption of Katla (i.e., Katla LLERS with tephra production over 1-4 days) is likely to produce substantial tephra deposition in southern Iceland. Ash dispersal has a substantial probability of reaching northern Europe, the UK (5-20\%) and central Europe $(\sim 5 \%)$ with concentrations exceeding $2 \mathrm{mg} \mathrm{m}^{-3}$ at any FL.
- An eruption of Askja similar to that of 1875 (i.e., Askja OES 1875 type) is likely to produce massive tephra deposition in eastern Iceland. Ash dispersal has a substantial probability of reaching northern Europe, the UK (5$20 \%)$ and central Europe $(\sim 5 \%)$ with concentrations exceeding $2 \mathrm{mg} \mathrm{m}^{-3}$ at any FL.

- An eruption of Eyjafjallajökull similar to 2010 (i.e., Eyjafjallajökull LLOES 2010 type) is likely to produce moderate tephra accumulation south of the volcanic edifice around the town of Vik. For computational reasons, probabilistic approaches to assess the airborne concentration resulting from such a long eruption were not applied.

Finally, in order to compare the relative impact of the different scenarios, one historical eruption was selected for each volcano for which ash dispersal and atmospheric concentrations were assessed using the same wind conditions of the Eyjafjallajökull 2010 eruption. The selected eruptions include Hekla 1947, Katla 1918, Eyjafjallajökull 2010 and Askja 1875. The conclusion is that all eruptive events, if they were to occur, would likely disrupt the European air traffic, with the most important perturbations caused by eruptions like Katla 1918 and Hekla 1947.

\section{National-scale vulnerability and impacts}

\subsection{Exposed targets}

In order to assess vulnerability and estimate potential impacts of tephra fallout in Iceland, one needs first to identify the "social, economic, environmental or cultural assets in areas that may be impacted by a hazard" (Birkmann, 2013, p. 305). The main exposed targets have been identified based on the scientific literature on tephra fallout impacts. In detail, the exposed targets that we consider are as follows:

1. Population: Iceland has 320000 inhabitants, of which 120000 live in Reykjavik, the capital. About $60 \%$ of the total population lives in the so-called Greater Reykjavik (Supplement Table S1). Recent trends (Byggdastofnun, 2012) show that the population is growing around the 
capital and in the eastern part of the country, where tephra fallout has high probabilities of occurrence for some of the eruption scenarios considered (Biass et al., 2014). The central part of the island is mostly uninhabited. Approximately one-quarter of the population has reduced mobility: $15 \%$ of inhabitants are under 10 years old and 9\% are over 70 (Statice, 2012). This segment of the population is potentially more exposed to suffering respiratory difficulties due to the presence of suspended $\mathrm{PM}_{10}$ (Baxter et al., 1983; Horwell and Baxter, 2006). In addition, all of the population is exposed to indirect impacts due to failure of services (water and electricity supply, transportation, access to health care). Data on population for each municipality and percentage of exposed people are available in Table $\mathrm{S} 2$ in the Supplement.

2. Emergency facilities, (e.g., hospitals, emergency shelters, police and fire stations): the two main Icelandic hospitals are located in Reykjavik, but other hospitals and local health centers, also considered in our analysis, exist in relevant towns such as Akureyri, Isafjordur, Nordfjordur and Selfoss. Police and fire stations are quite well distributed amongst the main towns. Finally, shelters are usually public buildings located close to areas of interest (monuments, touristic attractions) and towns, but for simplicity we only consider schools as possible shelters.

3. Mobility network (e.g., road network and mobility nodes such as ports and airports): the road network is directly exposed to tephra fallout, which may disrupt traffic, reducing the capability of the population to reach critical facilities and indirectly affecting services and productive activities. In the absence of a railway network in Iceland, the road network is extremely important for internal mobility. A main primary road circles Iceland along the coast. Disruption of the mobility network, even if temporary, can trigger relevant cascade effects. Ports are extremely important for the import/export activities in Iceland. In 2006, a total of $6 \mathrm{Mt}$ of freight passed through Icelandic ports, which mainly export marine products ( $25 \%$ ) and import/export "other goods" (49 and $51 \%$, respectively), including textiles and manufacturing goods (Statice, 2012). Finally, airports are also important mobility nodes. The main airport in Iceland is Keflavik, which accounts for more than 97 and $99 \%$ of international passengers and freight traffic (Isavia, 2012), respectively. Important airports for domestic routes are Reykjavì and Akureyri, accounting for approximately 25 and $50 \%$ of domestic passengers and 47 and $20 \%$ of freight (goods and mail), respectively (Isavia, 2012). Other smaller airports, including Egilsstadir, account for $12.5 \%$ of domestic traffic of passengers. The volume of the domestic air traffic is modest (around 800000 passengers per year; Isavia,
2012) but nonetheless important for the national economy, given the absence of a railway.

4. Electricity network: the electricity network is a critical infrastructure for economic activities and society in general. Electricity networks are very vulnerable to volcanic fallout (Wilson et al., 2009a, 2011), and consequences of a disruption of power generation and distribution are potentially dramatic. In Iceland, around $85 \%$ of the primary energy is produced domestically from renewable energy sources. In 2011, electricity was produced almost entirely from hydroelectric $(73 \%)$ and geothermal $(27 \%)$ plants. More than 30 hydroelectric plants are spread across the country, except in the southern area of the Vatnajökull ice cap (Icelandic National Energy Authority, 2012a), and up to 7 geothermal plants are located around the capital and in the northeast (Icelandic National Energy Authority, 2012b). Some of them are combined heat and power plants, which utilize geothermal water and steam.

5. Economic activities: the main economic activities in Iceland are services and industry, which in $2011 \mathrm{em}$ ployed 75.7 and $18.4 \%$ of the working population, respectively (Landshagir, 2012). Comparison between Greater Reykjavik and other regions shows that services in the capital region share a higher percentage of employees while industry dominates elsewhere (Landshagir, 2012). In particular, aluminum smelters are strategic components of the Icelandic economy, constituting $37.6 \%$ of the total Icelandic exports and placing the country in the top-20 aluminum-producing nations worldwide. In 2011, aluminum smelting accounted for approximately $73 \%$ of the gross electricity consumption (Landshagir, 2012).

6. Agriculture: the main agriculture activities are related to the production of wool and milk, which only account for a small percentage of the national GDP (Johánnesson, 2010). The distribution of the main agricultural areas (extracted from the Corine Land Cover raster map; see the Supplement Fig. S1) shows that a substantial part of the island is covered by snow and ice, and the few agricultural areas are barely visible and located in the proximity of main villages and coastal areas. Nevertheless, agriculture is important for local development, being the main economic resource for people living in small, isolated villages. Crops can suffer from short- to longterm impacts due to tephra accumulation (Wilson et al., 2009b). Fluoride absorption can impact cattle due to its toxicity and, unless direct inhalation is not a large concern, its ingestion through plants and water can cause diseases (Dawson et al., 2010).

7. Water supplies: Tephra fallout can disrupt water supply networks and water treatment plants (Stewart et al., 
2006). In Iceland, the areas close to active volcanoes are not densely populated and the disruption of water supply in urban areas seems not to be a large issue. However, tephra fallout can contaminate ground and surface waters, which are in some cases used for domestic/agricultural use (about a $95 \%$ of the national water consumption relies on high-quality groundwater and only a $5 \%$ on surface water; Gunnarsdóttir, 2012). This is usually the case for isolated farms, where no official quality controls are performed and, consequently, more are exposed to this hazardous phenomenon. Moreover, farms can suffer the indirect impact of tephra fallout on livestock, as it can contaminate water used for drinking (Wilson et al., 2009a; Dawson et al., 2010).

This list of exposed targets is not exhaustive but accounts for the main aspects generally considered in the literature. Amongst all these exposed targets, we selected the most significant for the national context based on practical considerations and data availability. Figure 2 shows maps of the considered features, based on several data sources: the national GIS data set (Landmælingar Islands, 2012), the European statistics database (Eurostat, 2013) and the Iceland National Statistics (Statice, 2012). In detail, Fig. 2a shows the location of the critical features considered (hospitals and schools that could be potentially be used as shelters), as well as the national road network. Our systemic vulnerability analysis is based on how easy it is for the population to reach critical facilities using the road network. Figure $2 b$ shows the location of hydroelectric power plants and the electricity distribution network. The most densely populated areas and the main productive activities (aluminum smelters) are also displayed on the map. Figure 2c shows the location of mobility nodes relevant for the Icelandic socioeconomic system. Airports can be directly disrupted not only by tephra fallout but also by tephra dispersal in the atmosphere, which may cause airspace closure. Import/export activities at ports and airports can suffer indirect damage due to the disruption of the road network, power plants and productive activities.

\subsection{Vulnerability assessment}

As mentioned, our vulnerability assessment focuses on the systemic and economic dimensions of vulnerability. This choice results from numerous factors, related partly to scientific and methodological aspects, including (i) the low probability of the exposed population suffering from relevant structural failure of buildings, and human casualties resulting from tephra accumulations suggested by the hazard analysis; (ii) the scale of the vulnerability and impact assessment (i.e., the whole country); (iii) the priorities for improving effective mitigation strategies in Iceland, defined through close cooperation between local stakeholders and the Icelandic Civil Protection; and (iv) the availability of accurate and up-todate data. As a result, based on the different categories of

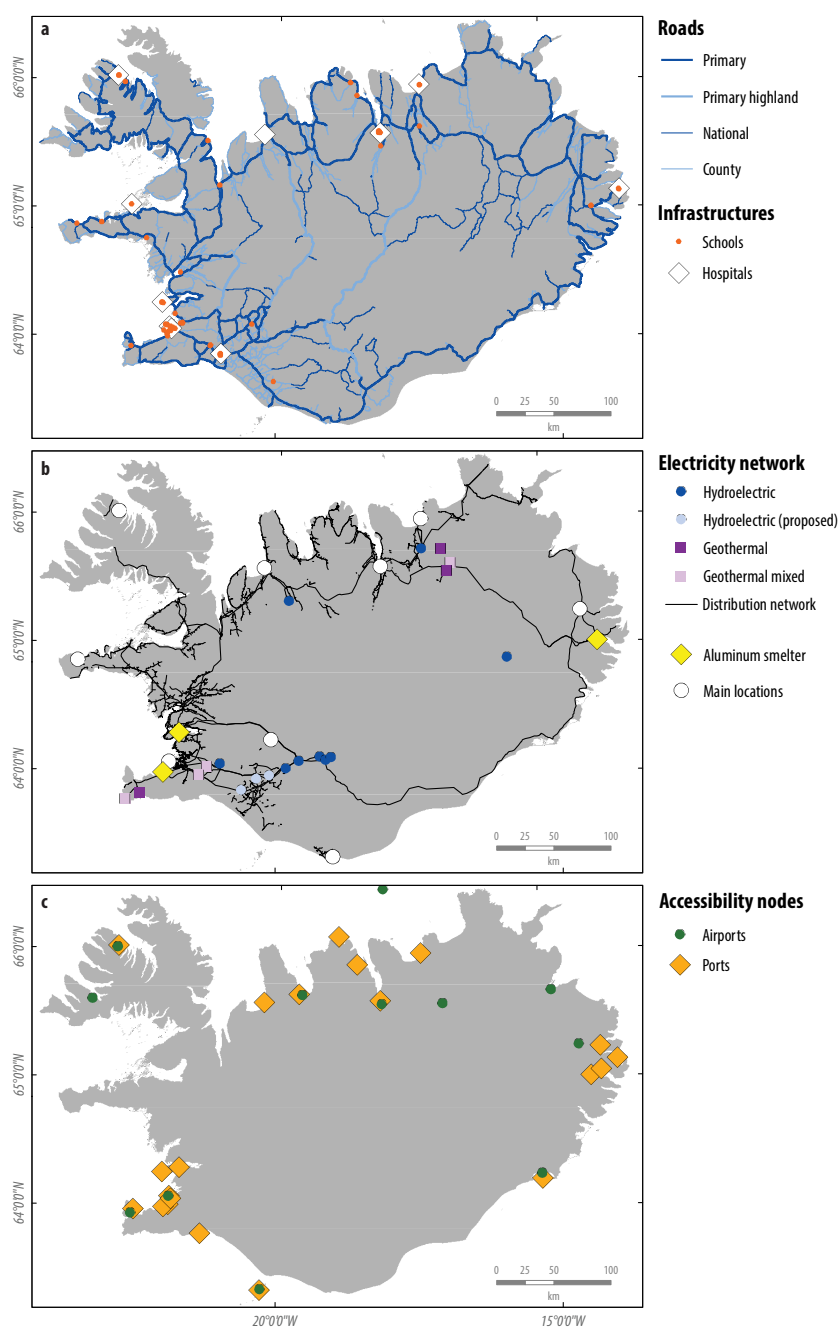

Figure 2. Exposure maps for (a) the road network and critical infrastructures (hospitals, local health care centers and schools, which can be used as ash shelters); (b) electricity distribution network, hydroelectric and geothermal power plants, production sites and main locations (urban areas); and (c) main transport nodes: ports and airport.

exposed targets, we defined vulnerability themes and indicators (Table 2), focusing on the following aspects:

- physical vulnerability, limiting the analysis to electric power plants and distribution networks;

- systemic vulnerability, which refers to the interdependencies among exposed targets capable of reducing the overall functioning of the system itself and thus its capacity to react in the emergency phase following an event;

- economic vulnerability, which refers to the potential for temporary or permanent loss of economic activities and assets which are crucial for the Iceland economy and, consequently, for the maintenance of the level of 
Table 2. Indicators (and estimators) defined for the systemic vulnerability from tephra fallout.

\begin{tabular}{lll}
\hline Category & Theme & Indicator (at municipality level) \\
\hline Physical & $\begin{array}{l}\text { Electric power plants and } \\
\text { distribution network }\end{array}$ & Constant vulnerability $=1$ \\
\hline Systemic & Accessibility & $\begin{array}{l}\text { Travel time to critical facilities, energy } \\
\text { production sites and mobility nodes }\end{array}$ \\
\hline Socioeconomic & Agricultural areas & $\begin{array}{l}\text { Combination of three factors: agricultural } \\
\text { area, milk and wool production }\end{array}$ \\
\hline
\end{tabular}

welfare of the population. It is worth noting that economic activities (such as agricultural activities) or economic assets (industries, energy production sites etc.) can be indirectly affected by, for example, the interruption of transportation services.

Physical vulnerability has been quantified considering the hydroelectric power plants and the electricity distribution network due to their high vulnerability to tephra fallout (Wardman et al., 2012). Geothermal and combined-power plants are not considered because they are a priori much less vulnerable to tephra fallout given their thick reinforced concrete structure with few or no openings. We assign a vulnerability value of 1 to all exposed hydroelectric plants and aerial sections of the distribution network because detailed data to rank the vulnerability of each particular plant were not publicly available. The electricity distribution network has significant interdependencies with information infrastructures, other utilities and services, and economic activities (Pederson et al., 2006; Laprie et al., 2007; Beccuti et al., 2012). As a result, a disruption of hydroelectric plants and/or the distribution network may result in severe failures of dependent sectors, as demonstrated by the blackouts in Italy (2003) and Germany (2006), which impacted large areas of western Europe (Menoni and Margottini, 2011).

The systemic vulnerability assessment has been performed considering accessibility, which is a key issue during emergency situations. According to Bertolini et al. (2005), accessibility can be defined as "the amount and diversity of places that can be reached within a given travel time and/or cost". During a crisis, bidirectional accessibility is crucial for both evacuating the population to safe areas and dispatching rescue teams (Galderisi and Ceudech, 2010). Although the disruption of the mobility networks due to tephra accumulation is generally temporary, it can result in significant cascade effects reducing accessibility to and from inhabited areas, emergency facilities, mobility nodes, power plants or industrial sites, with relevant consequences in terms of increasing losses and slower recovery. Here we consider the accessibility to emergency facilities (hospitals and shelters) for using the road network. The driving time is assessed using the Spatial Analyst toolbox in Esri ArcMap 10.2 (Esri, 2012). The hierarchy of the road network is accounted for

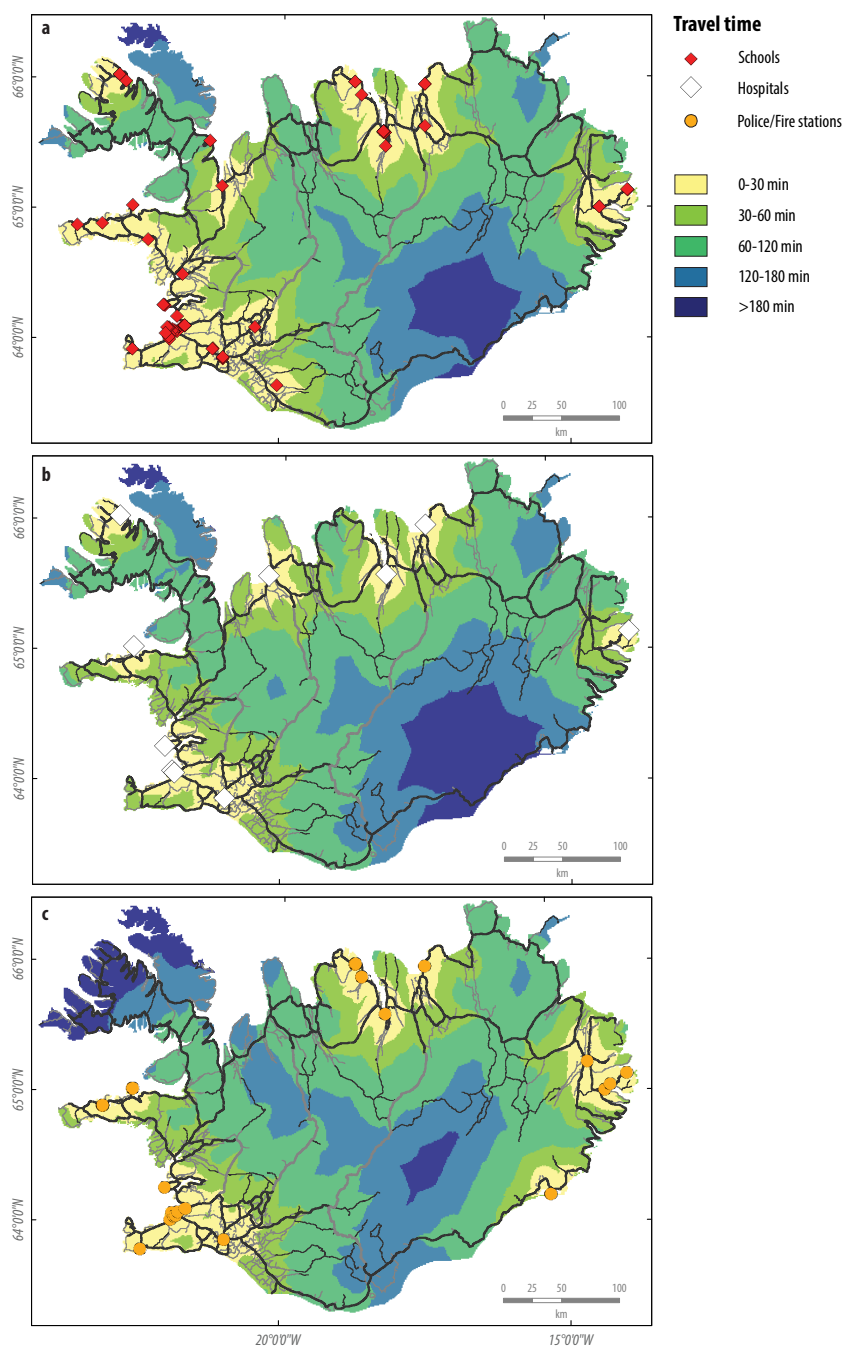

Figure 3. Accessibility to critical facilities: (from top to bottom) hospitals, schools and police/fire stations. All maps display the time in minutes required to reach a given facility by road.

using the official speed limits. Figure 3 shows the analysis of accessibility from inhabited areas to shelters, hospitals and fire stations. Based on this accessibility analysis we obtain the map of the most vulnerable areas. 


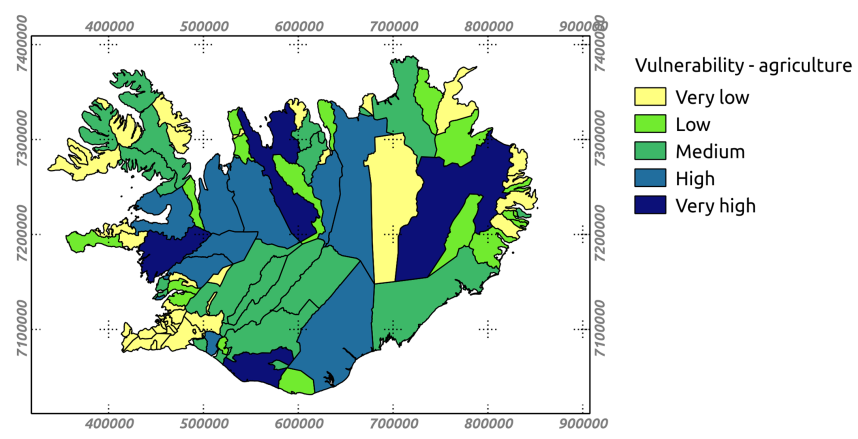

Figure 4. Thematic vulnerability map for agriculture. The five-class qualitative ranking is based on a combination of three indicators: production of milk, production of wool and percentage of agricultural area, all available at a municipality level. Maps for each indicator are given in the Supplement.

Finally, and given its complexity, quantity and diversity of data, the economic vulnerability assessment has been performed considering the agricultural sector only, assessing its relevance at a municipality level (Fig. 4). In order to estimate the importance of agricultural activities, we combine three different types of data: percentage of agricultural area, production of milk and production of wool. The percentage of agricultural area for each municipality was estimated by extracting pastures and crops from the CORINE Land Cover map (http://ec.europa.eu/agriculture/ publi/landscape/about.htm), containing an inventory of soil use information at high resolution $(100 \mathrm{~m})$. The production of milk $\left(\mathrm{L} \mathrm{year}^{-1}\right)$ and wool for each municipality during 2012 was provided by the Icelandic Regional Development Institute (Byggdastofnun, 2012). Wool production is expressed in terms of "support entitlements", i.e., the national entitlements that municipalities receive from the central government for their wool production and according to their percentage of the total production of the municipality (Á. Ragnarsson, personal communication, October 2012). Values of these three agricultural indicators have been classified in a five-class vulnerability ranking (very low, low, medium, high and very high vulnerability) using the natural breaks method (Jenks, 1967), commonly used in most GIS software and especially suitable for visualizing differences between classes (maps for each indicator are given in the Supplement Fig. S1).

\subsection{Impact assessment}

Before performing an impact analysis, it is necessary to determine the link between a quantitative hazard value (threshold) and each vulnerability indicator. Regarding the electricity network, there are two main impacts of tephra fallout: collapse/failure of network elements and flash-over of components. Wilson et al. (2011) define critical values of ash deposition for infrastructures based on well-documented impacts of past eruptions, and propose the value of $10 \mathrm{~cm}$ as a threshold for producing medium to high damages on network elements (towers, poles and lines). Moreover, Wilson et al. (2011) show that collapse of lines has happened for tephra fallout of a similar magnitude, while impacts on transformers can happen for lower fallout values. There is little evidence of impacts on power plants, but it is known that tephra fall is likely to cause disruption or shutdown (Wardman et al., 2012). In particular, coarse ash is more likely to cause tephra-induced abrasion on turbines, whereas a deposition of fine ash as thick as $50-100 \mathrm{~mm}$ may not cause strong abrasion. Moreover, in hydroelectric plants, tephra can engulf water channels and affect the turbines, limiting power plant functionality. Finally, Wardman et al. (2012) show that lower values of tephra fallout $(5-10 \mathrm{~mm})$ can cause tephra-induced insulation flash-over of components and provide a fragility curve for such a phenomenon. Thus, in order to include all effects, and according to the fragility curve, we assume that $1 \mathrm{~cm}$ tephra fallout has a $60 \%$ probability of causing disruptions of components. It is worth mentioning that we used a fragility curve for wet tephra, adopting a conservative approach, while dry tephra is not likely to produce flash-over.

Regarding the road network, tephra depositions $>1 \mathrm{~mm}$ $\left(\sim 1 \mathrm{~kg} \mathrm{~m}^{-2}\right)$ can cause a lack of visibility and disorient drivers, and can cause significant damage to vehicles' components and eventual engine failure (Wilson et al., 2011). However, this value does not take into account differences in road design, typology of vehicles, and other aspects such as a population's preparedness and coping capacity, which are becoming an important element in risk analysis (Frischknecht et al., 2010). In the case of Iceland, critical deposition thresholds for road disruption could be considerably higher due to the characteristics of the fleet of vehicles and the resilience of the population, who are used to coping with road traffic disruptions during winter snowfalls. We assume that a moderate disruption of the road network may happen with $\sim 10 \mathrm{~kg} \mathrm{~m}^{-2}$ tephra accumulation, while $100 \mathrm{~kg} \mathrm{~m}^{-2}$ would cause the total blockage of road transportation (Biass et al., 2012). Finally, we consider that an accumulation of $1 \mathrm{~cm}$ $\left(\sim 10 \mathrm{~kg} \mathrm{~m}^{-2}\right)$ can cause damages to agriculture and impact livestock (Wilson et al., 2009a; Biass et al., 2012), as has occurred during past eruptions in Iceland (Thorarinsson and Sigvaldason, 1971; Gudmundsson et al., 1992; Höskuldsson et al., 2007).

Overlapping probabilistic hazard maps with vulnerable features allows for the identification of potential impacts, which is conditioned to the occurrence of the considered eruptions (Biass et al., 2014). We estimated the number of power plants and the total length of the electricity network with respect to 5,10 and $20 \%$ probabilities of being impacted (i.e., covered by a critical tephra load $>10 \mathrm{~kg} \mathrm{~m}^{-2}$ ) if each scenario were to occur. Impacted features are identified by performing a GIS-based overlap of a probabilistic hazard map and an exposed target map (Fig. 2b). We assume that vulnerable parts of the network (Sect. 3.2) covered by 
Table 3. Estimated impacts on electricity generation and distribution systems for different eruptive scenarios. For each eruptive scenario, we calculated the length of the electricity distribution system and the number of power plants having 5,10 and $20 \%$ probability of being affected by a critical ash fallout of $10 \mathrm{~kg} \mathrm{~m}^{-2}$. Note that the 1947-type Hekla ERS has the highest impact on power plants due to the location of the volcano, close to five power plants.

\begin{tabular}{lcccccc}
\hline Probability $(\%)$ for $10 \mathrm{~kg} \mathrm{~m}^{-2}$ & 5 & 10 & 20 & 5 & 10 & 20 \\
\hline Eruptive scenario & \multicolumn{2}{c}{ Length impacted $(\mathrm{km})$} & \multicolumn{2}{l}{ Number of power plants } \\
\hline Hekla EES & 0 & 0 & 0 & 0 & 0 & 0 \\
Hekla ERS & 500 & 263 & 106 & 6 & 5 & 4 \\
Askja OES & 1400 & 655 & 109 & 5 & 4 & 1 \\
Katla LLERS & 671 & 267 & 135 & 6 & 4 & 0 \\
Eyjafjallajökull LLOES & 207 & 122 & 73 & 2 & 0 & 0 \\
\hline
\end{tabular}

tephra load greater than $10 \mathrm{~kg} \mathrm{~m}^{-2}$ (i.e., approximately $1 \mathrm{~cm}$ thickness) are expected to be disrupted, and contribute to the systemic damage. Impacts of lower tephra fallout values are not considered here, also accounting for the fact that not all components are necessarily directly exposed to tephra fallout. Expected impacts are displayed in Table 3. We partially account for the uncertainties related to the critical threshold choice by varying the probability of overpassing it between 5 and $20 \%$ (Tables 3 and 4). Note that Katla has a high impact on power plants at any value of probability considered, due to its close proximity to five power plants. Moreover, tephra fallout from a Hekla 1947-type eruption can impact important electricity lines that connect power plants to the rest of the network, while the occurrence of a Hekla 2000-type scenario has a low probability $(<5 \%)$ of impacting power plants and electrical infrastructure. Both the Hekla 1947 and the Katla scenario have a high probability (up to $20 \%$ ) of impacting important power lines that bring electricity to the southeastern region. An eruption at Eyjafjallajökull similar to that of 2010 could also impact these power lines (with a $10 \%$ probability). Finally, in the event of an 1875-type eruption at Askja, power lines may also suffer strong impacts. The occurrence of such a scenario may in fact disrupt an important line that connects the eastern part of the country with geothermal and hydroelectric power plants located in the north and provides electricity to an important aluminum smelter (Fig. 2b). Note that, although a Hekla 2000-type eruption does not seem to affect any power plant, Biass et al. (2014) show that low tephra accumulations $\left(\sim 1 \mathrm{~kg} \mathrm{~m}^{-2}\right)$ can be produced in the area surrounding the volcano, and thus the possibility of having impacts due to a Hekla 2000type scenario should not be discarded.

Biass et al. (2014) show that, if the considered eruptive scenarios defined for Katla and Askja were to occur, the probability of having tephra deposition of 10 and $1 \mathrm{~kg} \mathrm{~m}^{-2}$ in southern Iceland (ranging between 20 and 50\%) is substantial, while in eastern Iceland it is somewhat lower (5 to $20 \%$ ). Thus, agricultural activity in these areas can be impacted and livestock can suffer from fluorine intoxication due to water and soil contamination. We estimated the area devoted

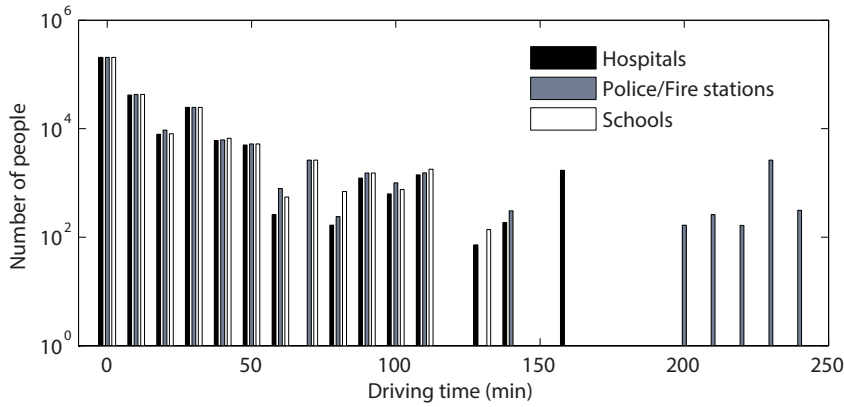

Figure 5. Number of people as a function of driving time to reach the closest critical infrastructures (i.e., hospital, police/fire station and schools).

to agricultural activities that has 5,10 and $20 \%$ probability of being impacted (i.e., covered by a critical tephra load $>10 \mathrm{~kg} \mathrm{~m}^{-2}$ ) in the case of each eruptive scenario occurring. Results are summarized in Tables 4 and 5 and can be compared with the corresponding tephra accumulation hazard maps and vulnerability maps (Fig. 4 and Supplement Fig. S1). The highest impacts on crops are caused by the occurrence of the considered LLERS at Katla, followed by a 2010-type LLOES at Eyjafjallajökull, while pastures are expected to be particularly impacted in the case of an 1875type OES at Askja and the considered LLERS at Katla. A 2000-type ERS eruption at Hekla is not likely to impact agricultural activities.

Impacts are also estimated on the basis of the accessibility analysis using least-cost-distance models (Wood and Schmidtlein, 2012). Using the census contained in the official GIS database (i.e., polygons of inhabited areas; Landmælingar Islands, 2012), we calculated the size of the population located in areas classified in terms of travel time (Fig. 5) to critical facilities: schools (Fig. 3a), hospitals (Fig. 3b) and police/fire stations (Fig. 3c). The Spatial Analyst toolbox of the ESRI ArcMap 10.2 software was used to calculate the shortest travel time from any pixel on the map to reach a critical facility using the road network. The hierarchy of the official road network (Landmælingar Islands, 2012) and the 
Table 4. Estimated impacts on agricultural activities for different eruptive scenarios. Area of crops and pasture having 5,10 and $20 \%$ probability of being affected by a critical ash fallout of $10 \mathrm{~kg} \mathrm{~m}^{-2}$. Katla LLERS and Eyjafjallajökull LLOES 2010-type scenarios cause the greatest impacts on crops, while pastures are particularly affected by eruptions of types Askja OES 1875 and Katla LLERS.

\begin{tabular}{lcccccc}
\hline Probability (\%) for $10 \mathrm{~kg} \mathrm{~m}^{-2}$ & 5 & 10 & 20 & 5 & 10 & 20 \\
\hline Eruptive scenario & \multicolumn{7}{c}{ Crops impacted $\left(\mathrm{km}^{2}\right)$} & \multicolumn{2}{c}{ Pastures impacted $\left(\mathrm{km}^{2}\right)$} \\
\hline Hekla EES & 0 & 0 & 0 & 0 & 0 & 0 \\
Hekla ERS & 10 & 0 & 0 & 281 & 13 & 0 \\
Askja OES & 10 & 1 & 0 & 586 & 287 & 26 \\
Katla LLERS & 14 & 7 & 1 & 361 & 125 & 101 \\
Eyjafjallajökull LLOES & 12 & 9 & 7 & 12 & 9 & 7 \\
\hline
\end{tabular}

Table 5. Indicators (and estimators) defined for systemic vulnerability of the European air traffic system to tephra dispersal.

\begin{tabular}{|c|c|c|c|}
\hline Vulnerability category & Vulnerability theme & Vulnerability indicator & Vulnerability estimator \\
\hline \multirow[t]{4}{*}{$\begin{array}{l}\text { Systemic } \\
\text { relevance of features }\end{array}$} & & $\begin{array}{l}\text { Airports (all of Europe and } \\
\text { northwestern Europe) }\end{array}$ & $\begin{array}{l}\text { Passengers }\left(n \text { day }^{-1}\right) \\
\text { Good }\left(\text { t year }^{-1}\right)\end{array}$ \\
\hline & & Routes (all of Europe) & $\begin{array}{l}\text { Number of average daily } \\
\text { connections }\end{array}$ \\
\hline & & Main Routes (northwestern Europe) & $\begin{array}{l}\text { Passengers }\left(n \text { day }^{-1}\right) \\
\text { Goods }\left(\text { t year }^{-1}\right)\end{array}$ \\
\hline & & Airspace sectors (FIRS, all of Europe) & Traffic rate per FIR \\
\hline \multirow[t]{3}{*}{ Socioeconomic } & Air traffic and & Population & Population/NUTS-2 \\
\hline & development & Air traffic & $\begin{array}{l}\text { Goods/NUTS-2 } \\
\text { passengers/NUTS-2 }\end{array}$ \\
\hline & & Accessibility & Multi-modal accessibility/NUTS-2 \\
\hline
\end{tabular}

speed limit for each road class were respected and implemented in a cost raster for accessibility analysis.

\section{European-scale vulnerability and impacts}

As clearly demonstrated during the Eyjafjallajökull eruption in 2010, the European air traffic system is largely vulnerable to loss of functionality of its elements when exposed to volcanic ash. The magnitude of systemic impacts depends on the relevance of the disrupted elements, and impacts of ash clouds can occur very far from the source (Ceudech et al., 2011). Here, we analyze the systemic vulnerability of European air traffic system and the socioeconomic vulnerability of the areas hosting its main airports.

\subsection{Exposed targets}

We define vulnerability indicators based on the analysis of European air traffic system, including main exposed airports and aviation routes. The analysis is performed at the European scale, but we focus on those regions where our hazard assessment indicates that impacts from ash dispersal can be significant.
The European air traffic network has more than 2000 international airports handling approximately 170000 overall daily flights on average (Wegner and Marsh, 2007). However, over $50 \%$ of the European air traffic is concentrated in the top 35 airports (Wegner and Marsh, 2007). The European air traffic network is scale-free (Wilkinson et al., 2001), meaning that these main hubs are the most relevant to the system, and therefore highly vulnerable to its failure. The main European hub is London Heathrow, with 61 million terminal passengers on international flights in 2010 (Heathrow Airports, 2013), followed by Paris Charles de Gaulle. The five London airports (Heathrow, Gatwick, Stansted, Luton and London City) account together for more than $60 \%$ of the total number of UK passengers according to the UK Department of Transport. In 2011, London's airports handled more than 120 million passengers and 1.7 Mt of freight (CAA, 2012). Moreover, the most intense freight traffic in Europe during 2009 was between the UK and four European states: Germany, Netherlands, France and Belgium (PricewaterhouseCoopers, 2011). The London area is therefore one of the most critical and strategic points within the European air traffic network, and the airspace between London, Paris, Frankfurt and Amsterdam constitutes the densest part of the European civil aviation network. It therefore follows that the European air traffic 
network is particularly vulnerable to the failure of some of these strategic hubs.

At a national level, Keflavík airport is also strategic for the Icelandic economy. In 2011, Keflavík handled $97.5 \%$ of all international passengers (1.75 million; Keflavík International Airport, 2012), $49.2 \%$ of domestic passengers (0.75 million), and more than $99 \%$ of all cargo operations. Airbased commercial relationships with Europe are very important for the Icelandic socioeconomic system. In fact, the European Economic Area market (i.e., the 27 EU countries plus Iceland, Norway and Liechtenstein) accounts for 82.7 and $61.9 \%$ of total Icelandic exports and imports, respectively. The main commercial partners are Netherlands, Germany, the UK, and Norway. Iceland's imports come mainly from Norway, USA, Germany, Netherlands and the UK (Statice, 2012). According to the 2011 statistics, Keflavík's most important passenger destinations were Copenhagen, London and Oslo. During the period of 2010-2011 the Icelandic airspace experienced a $9 \%$ growth in traffic (counting overflights) (Isavia, 2012), and, although peripheral in the European network, it is strategic for intercontinental flights from and to the USA and Canada. Disruption of air traffic connections can therefore substantially impact on both local and regional economies.

Based on these considerations, the exposed targets for our systemic vulnerability analysis are the main airports and routes to north and central Europe and the most relevant socioeconomic features of the areas where the main airports are located. In order to have a vulnerability assessment meaningful to civil aviation stakeholders, we consider European airspace sectors, following the current classification (EUROCONTROL, 2005). Flight Information Regions (FIRs) are subdivided according to their specific role into CTA (control area), OCA (oceanic control area), ACC (area control center) and UAC (upper area control), which are airspace sectors not hosting airports (EUROCONTROL, 2005). Aerial sectors represent a key component of the air traffic network because each sector has an associated capacity, which is the main parameter for air traffic management (Leal de Matos and Ormerod, 2000; Leal de Matos and Powell, 2002; Dell' Olmo and Lulli, 2003).

Finally, we note that the territorial context of an airport is also relevant for the estimation of socioeconomic vulnerability and impact because the vulnerability of a region is proportional to its dependence on air traffic.

\subsection{Vulnerability indicators}

Table 5 summarizes the systemic and socioeconomic vulnerability indicators defined for the European air traffic system. Figures 6-10 show vulnerability maps produced for the considered features (airports, routes, airspace sectors and European regions). Visualization is performed through the open source GIS Qgis (http://www.qgis.org/en/site/), using the European GIS database (GISCO, 2013) and European air traffic database (courtesy of EUROCONTROL). Unless specified otherwise, all indicators are reclassified into a qualitative five-class ranking, ranging from very low to very high, using the natural breaks method (Jenks, 1967). Vulnerability indicators include the following:

1. Strategic airports. We assume that the higher the traffic of an airport, the higher its relevance and, consequently, the higher the vulnerability of the system to its potential disruption. We classified all European airports according to traffic of passengers and freight during 2012 (Eurostat, 2013), and this identified Frankfurt, London Heathrow, Amsterdam and Paris Charles de Gaulle as the strategic elements for the European air traffic system in terms of passengers and goods. Given that the probability of ash dispersal affecting southeastern Europe is low (Biass et al., 2014) and that we aim to assess the vulnerability within a more constrained domain, we performed the same analysis for central and northwestern Europe. Having selected the most relevant airports in central and northern Europe in terms of air traffic values (Supplement Table S3), we ranked them according to passengers and freight values (Fig. 6). The most relevant airports are London Heathrow, Paris Charles de Gaulle, Frankfurt, Amsterdam and Munich, which have already been identified as main hubs at the European level. Copenhagen airport also has a high relevance for traffic to northern Europe (including Iceland).

2. Strategic routes, classified in two ways. The first classification builds upon the average number of connections between each pair of European airports in 2012 (courtesy of EUROCONTROL). We assume that the higher the number of connections the higher the importance of the route and the higher the systemic vulnerability of the system to its failure. This classification reveals that the top five connections are Madrid-Barcelona (Spain), Istanbul-Izmir (Turkey), Paris-Toulouse (France), Oslo-Bergen (Norway) and Barcelona-Palma de Mallorca (Spain). Constraining the analysis to central and northwestern Europe, the most relevant connections are London-Paris, Paris-Frankfurt, London-Edinburgh, London-Dublin, Munich-Frankfurt, Copenhagen-Aalborg, OsloTrondheim, Oslo-Bergen and Oslo-Stavanger. This analysis underlines that the main city pairs are often composed of national connections between first- and second-largest cities, as described by Wegner and Marsh (2007). The second classification is based on air traffic (passengers and freight) for each city pair, i.e., for the main routes between a considered airport and its partners (Eurostat, 2013). This kind of classification considers the relevance of European routes for a selected sub-system constituted by the considered airport and its main European partners. For example, we show two relevant cases: the London 

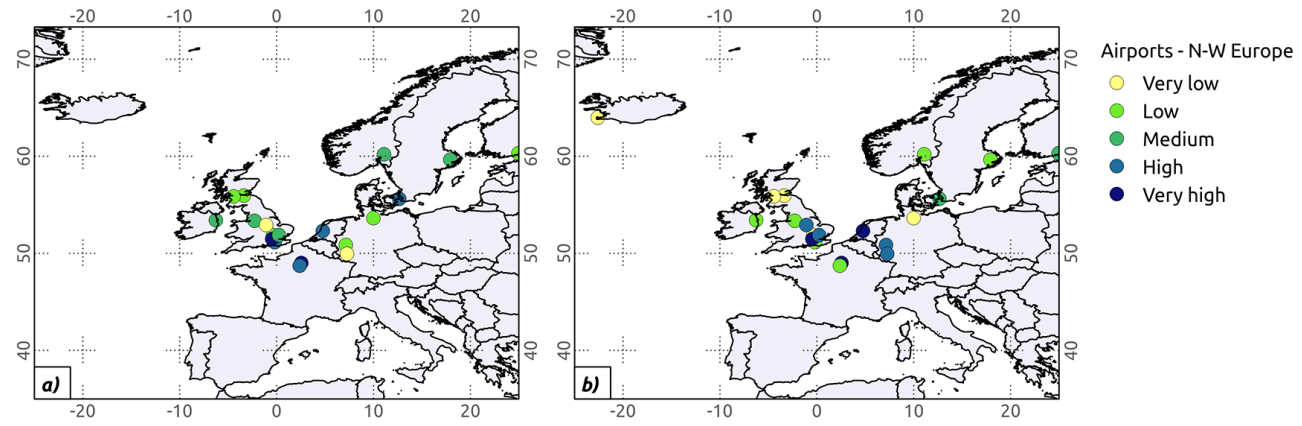

Figure 6. Main airport hubs in central and northwestern Europe depending on the traffic of passengers (a) and goods (b) during 2010 (Eurostat, 2012). The values represent the relevance of these airports for passengers and freight air traffic. The most relevant airports are London Heathrow, Paris Charles de Gaulle, Frankfurt, Amsterdam and Munich.
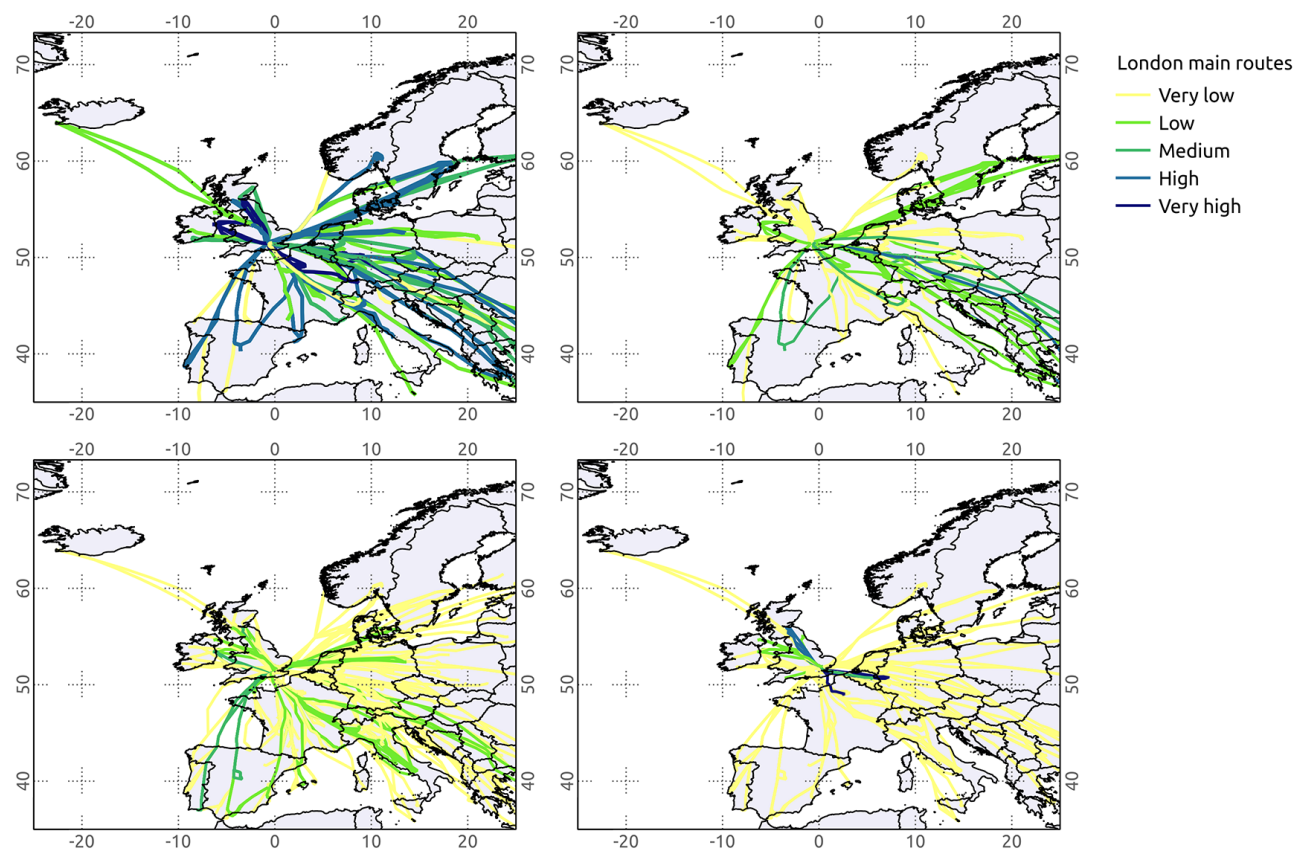

Figure 7. Main European routes from/to London Heathrow (top) and the rest of the airports in Greater London (Gatwick, Luton and Stansted, displayed together, bottom). Routes are ranked according to their importance in terms of passengers (left) and freight (right) traffic. The vulnerability classification is based on the whole range of air traffic data between main London airports and the considered European airports in 2010 (Eurostat, 2012). The same classification criterion is used for all figures and the comparison underlines that Heathrow airport handles the most strategic routes (corresponding to more than 1.2 million passengers per year).
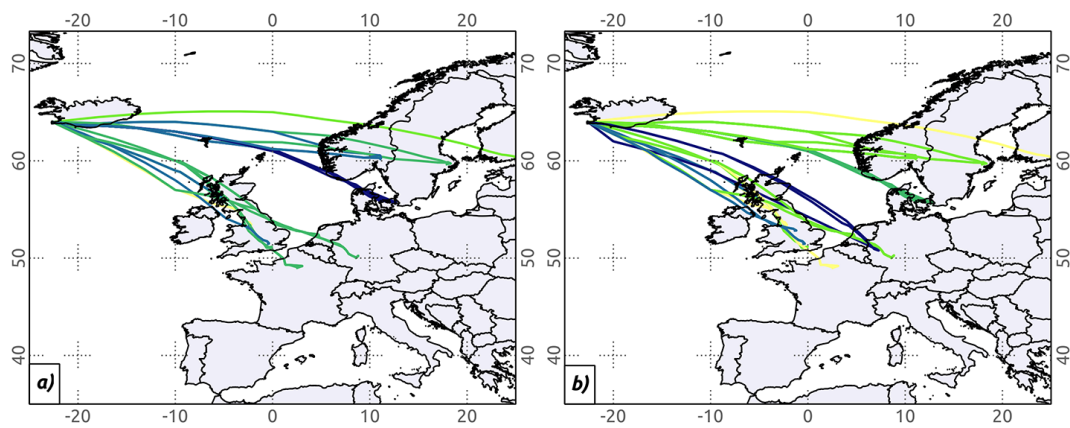

Keflavik main routes

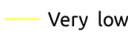

- Low

- Medium

- High

— Very high

Figure 8. Main European routes of passengers (a) and freight (b) from/to Keflavík airport. Analysis is performed for the routes connecting the main airports shown in Fig. 6. The vulnerability classification is based on 2010 data (Eurostat, 2012). 
hub, strategic for European air traffic, and Keflavík airport, the most important in Iceland. The relative importance of routes is a measure of the vulnerability of the sub-system to the disruption of that particular route. In our analysis, the London hub includes the city's four main airports: Heathrow, Gatwick, Stansted and Luton. Figure 7 shows strategic routes of London airports for passengers (left) and freight (right), for Heathrow airport (top) and for the other three airports, displayed together (bottom). The top London destinations ( $>1.2$ million passengers year ${ }^{-1}$ ) are Dublin, Edinburgh, Paris and Frankfurt. London Heathrow-Dublin is the most important connection, with more than 1.5 million passengers per year. In terms of cargo, Stansted is also an important hub with main destinations to Frankfurt, Brussels, Stockholm and Paris. Figure 8 shows the most important partners for Keflavík airport in terms of passengers (a) and goods (b). Copenhagen, London and Oslo are strategic destinations for passengers, whereas Amsterdam, London, Paris, and Cologne-Bonn are main nodes for freight transportation. It is worth noting that the main passenger routes from Keflavík airport have the same order of magnitude as the less relevant route for the London hub ( 300000 passengers per year). Keflavík routes, if classified using the same range used for the London airports, would fall into the low-vulnerability class, and their relevance would be diminished in the subsequent impact analysis. Using a scale-dependent classification criterion allows for identification of routes that can be secondary at a broader European scale but are strategic for the national scale.

3. Number of daily European flights in each airspace sector, which gives a measure of the airspace congestion. For simplicity, our analysis uses data of one of the peak days during 2012 (29 June) and assumes that this particular day is representative of high-traffic situations in Europe. For each airspace sector, we counted how many times per day the sector is crossed by flights at any FL and assign a vulnerability value accordingly. Figure 9 shows that the most congested airspace sectors are located in France (Brest, Paris and Marseille FIRs), the southern UK (London FIR), Germany (Langen, Bremen and Hannover FIRs), Netherlands (Amsterdam FIR), and Italy and Spain (Milan, Rome and Madrid FIRs). Some FIRs show lower traffic rate compared to the surrounding areas, for example Ireland (Shannon FIRs) and other regions of France (Bordeaux and Reims FIRs).

4. Relevance of air traffic for European regions, based on a combination of four regional indicators: population (Eurostat, 2013, data from 2012); total number of passengers and tonnes of freight transported by air (Eurostat, 2013, data from 2011); and multimodal accessibility, which takes into account the

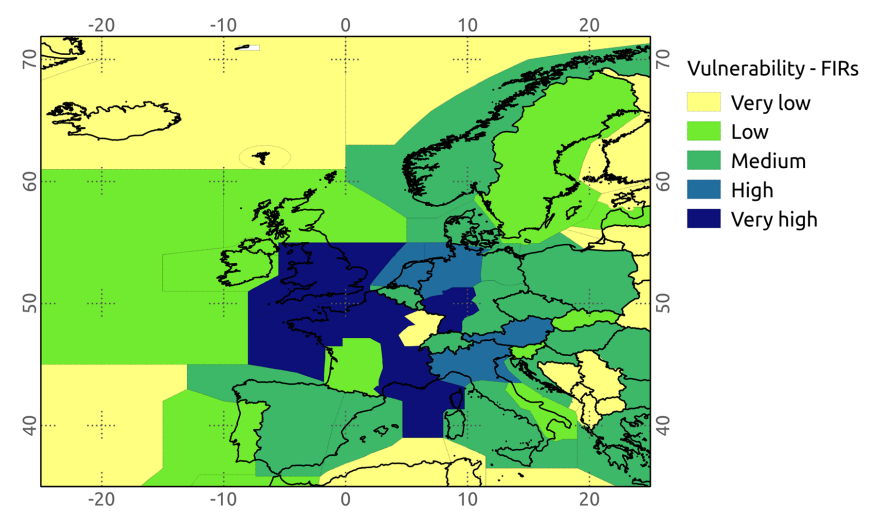

Figure 9. Vulnerability classification of the European airspace sectors based on the air traffic rate in the sector during a peak day of 2012 (source: EUROCONTROL, 2012). FIRs with very high vulnerability values (blue) are London, Paris and Munich.

presence/absence of alternative transport modes and their cost (ESPON, 2004; TRACC, 2010, p. 17). We use multi-modal accessibility produced by the ESPON project $\left(\mathrm{ESPON}^{\circledR}, 2013\right)$ as an indicator of vulnerability: areas with low multi-modal accessibility are therefore more vulnerable to the failure of one transportation mode due to the limited variety of alternative transportation modes available. According to Fürst et al. (2000), multi-modal indicators have much more explanatory power with respect to regional economic performance than any accessibility indicator based only on a single mode. We propose a first-level assessment of socioeconomic vulnerability by combining these four indicators under the assumption that vulnerability increases when the dependency on air traffic is higher and the multi-modal accessibility lower. All indicators refer to the 2003 NUTS-2 regions (Nomenclature of Territorial Units for Statistics), a hierarchical system for dividing the economic territory of the EU for the application of regional policies. We combine the four indicators by summing the values for each NUTS- 2 region, and reclassifying the resulting map into five vulnerability classes. Population, air traffic and multi-modal accessibility are classified into five equal interval classes, while the multi-modal accessibility database produced by the ESPON project is already ranked into five qualitative classes, ranging from 1 (highly below average) to 5 (highly above average). Air traffic data show that the areas which most rely on air traffic correspond to the regions hosting the main European cities of London, Paris, Frankfurt and Amsterdam. But socioeconomic vulnerability is not only related to the volume of air traffic: for example, Ireland has a low multimodal accessibility (Supplement Fig. S2) but a considerable population (Supplement Fig. S2). The resulting vulnerability map (Fig. 10) facilitates recognition of the 


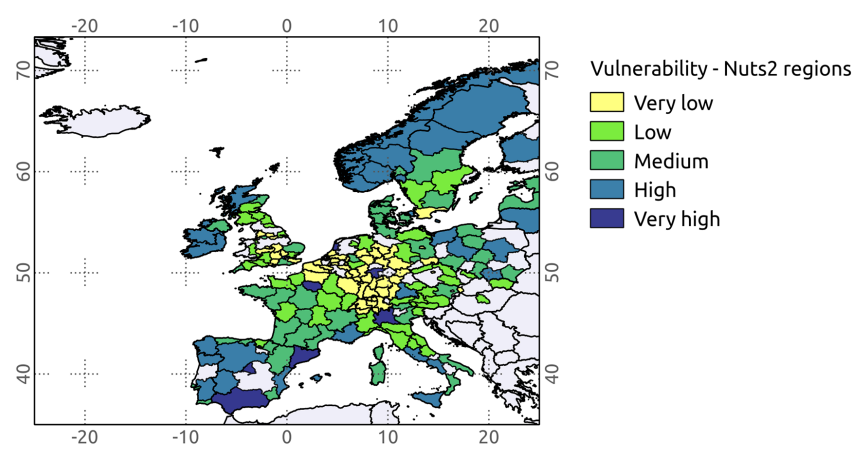

Figure 10. Vulnerability of the NUTS-2 regions, calculated as a combination of population, air traffic values and multi-modal accessibility value (see the Supplement Fig. S2 for individual maps). High-vulnerability areas are those having high population and low accessibility rates, for example Ireland and Norway.

areas most dependent on air traffic, where a relatively high population and/or air traffic values are associated with low multi-modal accessibility. The most vulnerable NUTS-2 areas are therefore the ones hosting the cities of London, Paris, Frankfurt and Amsterdam. Also, Ireland, Norway and northern France show a mediumhigh vulnerability. Due to the intrinsic nature of being an island, air traffic cannot easily be substituted by alternative transportation means. For this reason, Ireland has medium vulnerability to air traffic disruptions.

Given the differences in the indicators of vulnerability, we evaluate the expected impacts for each single vulnerability feature, i.e., for the national-scale assessment, we do not merge the different thematic vulnerability maps (Figs. 610) into a single map. However, once the strategic elements and their relevance are identified, it is possible to assess the expected impacts of each eruptive scenario through a GISbased overlap of hazard and vulnerability maps.

\subsection{Impact assessment}

We propose three different methods for assessing the impacts of tephra dispersal on European air traffic. Each method focuses on producing specific results, and could be used to support risk management strategies at different levels. It should be kept in mind that impact assessment results are conditioned to the occurrence of the eruptive scenario (Biass et al., 2014).

The first method consists of a qualitative GIS-based visual overlap of hazard and vulnerability maps. The graphical overlap allows for an immediate identification of the routes that have the highest probability of being disrupted for each scenario. For example, the overlap of the Askja hazard map for all FLs and the main passenger routes between London Heathrow and Europe (Fig. 7a) reveals which routes would have the highest probability of being disrupted in this scenario. The overlap of hazard and vulnerability can also be performed using hazard maps for specific FLs and averaged arrival time and persistence maps, which allow for the potential duration of a disruption to be inferred.

The second method estimates the impact (movements disrupted, passengers and freight stranded) at given airports by multiplying the average atmospheric persistence time of a given hazardous ash concentration for a given eruptive scenario by the hourly averaged traffic. Here, we assume that, if the critical ash concentration is reached at any FL over an airport, all flight operations are disrupted. For example, Tables 6 and 7 show the expected impacts at London Heathrow and Keflavík airports for the different eruptive scenarios considered, respectively. Air traffic values for London Heathrow are estimated dividing yearly averages (CAA, 2012; Heathrow airport, 2013) by 365. Keflavík air traffic values are inferred from the Keflavík airport 2011 facts and figures document (Keflavík International Airport, 2011). According to Biass et al. (2014), the conditional probability of having more than $24 \mathrm{~h}$ of disruption at London airports from Askja 1875 and Katla 1918 scenarios is about 5 and $1 \%$, respectively. The conditional probability of having more than $24 \mathrm{~h}$ of disruption due to Hekla activity is lower than $1 \%$. Thus, there is a substantial probability of having strong disruptions in the London area due to high-magnitude explosive volcanic eruptions at Askja and Katla, and a low probability of having impacts at London due to lower magnitude events at Hekla.

Finally, the third method consists of overlapping hazard and vulnerability data and combining the values on a cell-bycell basis, i.e., multiplying hazard and vulnerability values within each cell. To do that, hazard and vulnerability maps are converted to raster format (GeoTIFF) using GRASS GIS (Neteler et al., 2012). We use probabilistic hazard maps for each scenario that account for the probability of disruption at any FL (Biass et al., 2014) and vulnerability maps of the airspace sectors (Fig. 9). Such maps are then overlapped on a cell-by-cell basis and the resulting impact map is reconverted to vector format, aggregating the maximum impact value over FIRs areas. The final results are impact maps containing impact values for each FIR, reclassified into five qualitatively impact classes (very low to very high impact) using the natural breaks method. These results are shown in Fig. 11. It has to be stressed that the resulting impact represents relative comparison between FIRs rather than a quantitative impact. The Hekla ERS 2000-type scenario (Fig. 11a) produces very high impacts in the Reykjavík FIR, high impacts in the London FIR and low impacts in the Shanwick OCA and the Norway FIRs, but is not expected to affect central Europe. The Hekla ERS 1947-type scenario (Fig. 11b) produces very high impacts in the Reykjavík FIR, and Paris, Brest and Marseille FIR; high impacts in the London FIR; and low impacts in the Shanwick, Norway and Sweden FIRs. Such a scenario is also likely to result in low impacts in the northern Germany and Poland FIRs. Both the Katla LLERS (c) and the Askja OES 1875-type (d) scenarios are likely to produce high impacts in the Keflavík FIR as well as the southern UK and 
Table 6. First-order estimation of expected impacts at London Heathrow airport for different eruption scenarios based on the averaged persistence. Air traffic values are based on yearly averages (CAA, 2012).

\begin{tabular}{lcccc}
\hline Eruptive scenario & $\begin{array}{c}\text { Mean persistence } \\
\text { all FLs (h) }\end{array}$ & $\begin{array}{c}\text { Movements } \\
\text { disrupted }(n)\end{array}$ & $\begin{array}{c}\text { Passengers } \\
\text { stranded }(n)\end{array}$ & $\begin{array}{c}\text { Freight } \\
\text { stranded }(\mathrm{t})\end{array}$ \\
\hline Hekla-2000 ERS & $\sim 3$ & $\sim 160$ & $\sim 23000$ & $\sim 600$ \\
Hekla-1947 ERS & $\sim 4$ & $\sim 180$ & $\sim 27000$ & $\sim 700$ \\
Katla LLERS & $\sim 10$ & $\sim 530$ & $\sim 78000$ & $\sim 2000$ \\
Askja OES & $\sim 8$ & $\sim 410$ & $\sim 60000$ & $\sim 1500$ \\
\hline
\end{tabular}

Table 7. First-order estimation of expected impacts at Keflavík airport for different eruption scenarios based on the averaged persistence. Air traffic values are based on the Keflavík airport 2011 facts and figures document (Isavia, 2012).

\begin{tabular}{lcccc}
\hline Eruptive scenario & $\begin{array}{c}\text { Mean persistence } \\
\text { all FLs (h) }\end{array}$ & $\begin{array}{c}\text { Movements } \\
\text { disrupted }(n)\end{array}$ & $\begin{array}{c}\text { Passengers } \\
\text { stranded }(n)\end{array}$ & $\begin{array}{c}\text { Freight } \\
\text { stranded }(\mathrm{t})\end{array}$ \\
\hline Hekla-2000 ERS & $\sim 5$ & $\sim 20$ & $\sim 950$ & $\sim 20$ \\
Hekla-1947 ERS & $\sim 8$ & $\sim 30$ & $\sim 1500$ & $\sim 40$ \\
Katla LLERS & $\sim 21$ & $\sim 90$ & $\sim 4300$ & $\sim 110$ \\
Askja OES & $\sim 18$ & $\sim 70$ & $\sim 3600$ & $\sim 90$ \\
\hline
\end{tabular}

France FIRs, mostly due to their high traffic rates (and therefore high vulnerability). These scenarios can also produce high impacts in the Norway, Sweden, Austria and Germany FIRs. Low impacts are expected in the rest of Europe.

\section{Discussion}

Outcomes of our impact assessment are derived from probabilistic analysis, which are conditioned to the occurrence of specific eruptions at specific volcanoes described in the hazard scenarios of Biass et al. (2014). Volcanoes were selected based on the probability of eruption and significance of associated impact, while the hazard scenarios were derived from field observations to be statistically representative. However, an eruption at a different volcano or a different type of activity at the selected volcanoes cannot be excluded, and therefore the impact in zone other than those identified in our assessment cannot be discarded. The main value of our work is the new multi-source, multi-scale strategy introduced to assess both hazard and impact at different scales that can be easily applied to other volcanoes and other hazard scenarios. Nonetheless, considering the wide range of hazard scenarios investigated and the statistically representative meteorological conditions analyzed at the European scale, our hazard and impact assessments can be considered as a first-level evaluation for the whole Icelandic region.

\subsection{National-level vulnerability and impact assessment}

The methodology presented here to assess vulnerability to tephra fallout at a national scale was developed for the particular case of Iceland in cooperation with local stakeholders and the Icelandic Civil Protection Department, and uses only publicly available data. However, the method could potentially be applied in different geographic and socioeconomic contexts where similar public censuses are available. The list of exposed features identified in Sect. 3.1 is valid elsewhere and Table 8 lists the type of data that, ideally, should be included in any comprehensive vulnerability assessment. For example, from a socioeconomic point of view, the role of productive activities and the number of employees for activity or sector should be taken into account. Industrial and tertiary activities, for example, often constitute the backbone of the socioeconomic system, driving local development and distribution of resources. In terms of transportation, one inconvenience is that national statistics are rarely given by transport mode, making it difficult to identify the precise contribution of air traffic to the socioeconomic system. Also, water supply has been recognized as an exposure target in a few isolated cases (Sect. 3.1) but is not taken into account for the estimation of impacts, because it needs to be treated at a more local scale. A census of water supply systems (for example, water quality control and monitoring) may support response strategies, in particular for areas with strong agricultural sectors (Fig. 4) that can suffer substantial impacts from tephra fallout (Sect. 3.3). Finally, only a few data sets were available at a municipality level or in the form of disaggregated data (that is, data available at the same administrative level used for collection). For example, most economic and labor market indicators were produced at the national level. This lack of disaggregated data is a common problem in most risk assessments, and the availability of disaggregated data sets, or data sources defined at lower administrative levels, would improve the vulnerability assessment presented here.

Figures 3 and 4 allow for the spatial distribution of the most vulnerable areas and targets to be identified according 

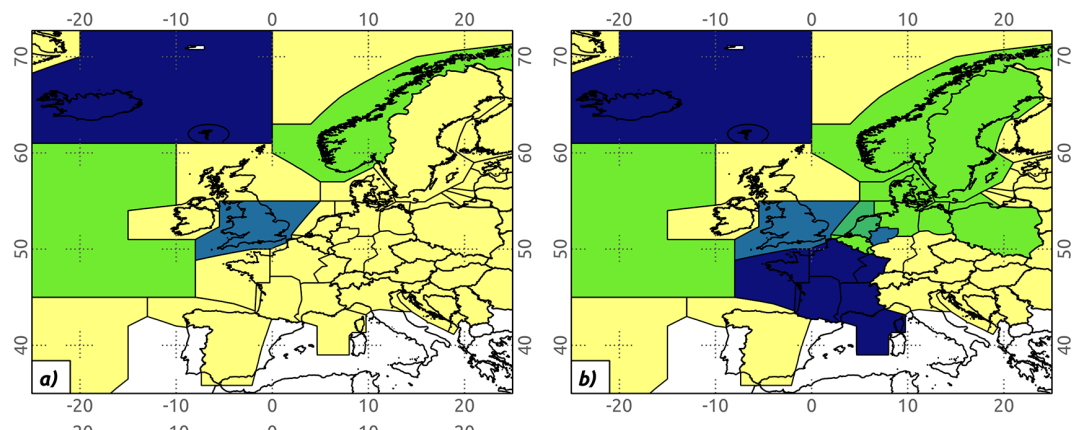

Impacts - all FLs

Impact on FIRs

$\square$ Very Low

$\square$ Low

$\square$ High

Very high
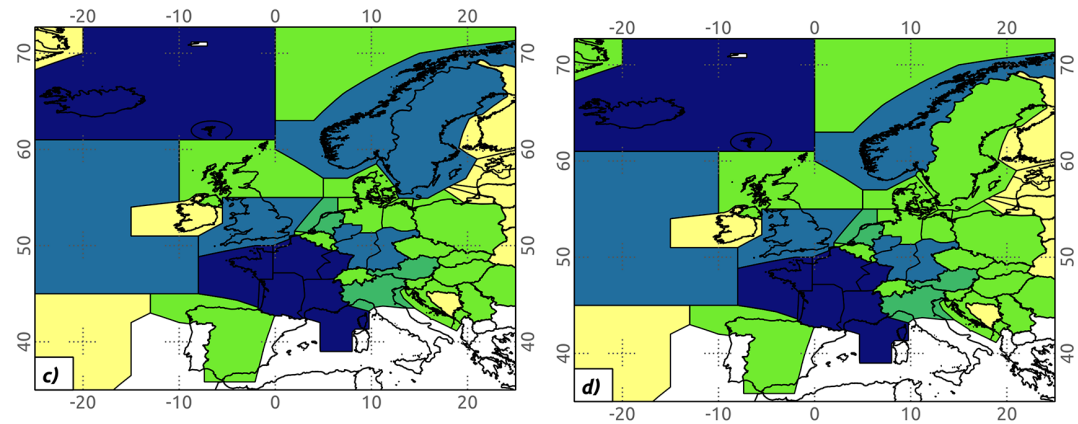

Figure 11. Expected impacts of tephra dispersal on European airspace sectors (FIRs) if the different scenarios considered were to occur: (a) Hekla 2000 type, (b) Hekla 1947 type, (c) Askja 1875 type and (d) Katla scenarios.

Table 8. Availability, sources and type of data used for the vulnerability assessment to tephra fallout at the national scale.

\begin{tabular}{lclll}
\hline Data & Available & Source & Coverage & Type \\
\hline Population & Yes & Statice & Municipalities & Number \\
Population trends & Yes & Byggðastofnun & Municipalities & Percentage \\
Population age & Yes & Statice & Municipalities & Number \\
Power plants & Yes & Landmælingar Islands & Disaggregated & Location \\
& & http://www.or.is/en/about & & \\
Aluminum smelters & Yes & Landmælingar Islands & Disaggregated & Location \\
Hospitals & Yes & Landmælingar Islands & Disaggregated & Location \\
Shelters & Yes & Landmælingar Islands & Disaggregated & Location \\
Police stations & Yes & Landmælingar Islands & Disaggregated & Location \\
Fire stations & Yes & Landmælingar Islands & Disaggregated & Location \\
Road network & Yes & Landmælingar Islands & Disaggregated & Digital map \\
Electricity network & Yes & Landmælingar Islands & Disaggregated & Digital map \\
Ports (import/export) & Yes & Statice & Disaggregated & Import/export values \\
Airports (air traffic) & Yes & Isavia & Disaggregated & Passengers/freight values \\
Land use & Yes & Corine Land Cover & Homogeneous areas & Corine classification \\
Milk production & Yes & Byggðastofnun & Municipalities & Liters/support entitlements \\
Wool production & Yes & Byggðastofnun & Municipalities & Support entitlements \\
Civil protection units & No & - & - & - \\
Productive activities & No & - & - & - \\
Employees for productive & & & & \\
activities/sectors & & & - & \\
Average income & No & - & - \\
Water supply & No & - & & - \\
\hline
\end{tabular}


to the considered vulnerability themes. It is important to stress that the vulnerability scores, expressed either as numerical scores or qualitative judgments, normally represent comparative (i.e., relative) values. This makes the merging of different vulnerability maps into a single final map a complex process. On the one hand, the perspective of single indicators can be lost when combined with others. On the other hand, single merged maps are more synthetic and workable if they involve no loss of information. In this work, and given the very different nature of the indicators considered, we prefer not to overlap maps of different vulnerability categories. Nonetheless, the comparison of information related to each vulnerability indicator can provide a significant support both to land use and emergency planning.

Results from national vulnerability and impact assessments allow for definition of priority areas for risk mitigation strategies. Comparison of population values with other vulnerability indicators can support the prioritization of interventions for long-term vulnerability mitigation plans. For example, northeastern Iceland has a substantial probability of being affected by deposition of tephra in the case of an OES occurrence at Askja, and this hazardous phenomenon should be considered in long-term territorial plans. Recent population statistics (Byggðastofnun, 2012) show a positive trend in this area due to the construction of a dam and the consequent generation of employment. The increase in population and the arrival of non-local workers, less familiar with an active volcanic environment, should be taken into account, e.g., through educational programs. The results of the impact assessment can also support Icelandic policies in the main strategic sectors such as transportation, economic activities or location of critical facilities. Table 3 shows that the largest impacts are expected from the occurrence of selected eruptive scenarios (Table 1) at Askja, Katla and Hekla, due to the presence of power plants and a main power line in their surroundings. Results suggest that moderate tephra fallout from a 1947-type ERS at Hekla can have major impacts on the surrounding power plants. Occurrence of low-magnitude 2000type ERS activity at Hekla does not seem to produce such major impacts but, given its very high frequency (10-year repose time; Höskuldsson et al., 2007), should also be taken into account. In fact, repeated tephra fallout could have longterm impacts on power plant equipment and external components. Expected impacts on agricultural activities are in general limited to the few crops located in the southeast of the island. Table 4 shows that the major impacts on crops are expected in the case of an LLERS at Katla and a 2010type LLOES at Eyjafjallajökull. Moreover, ash fallout from the occurrence of eruptive scenarios at Askja and Katla is expected to cover several square kilometer of pasture in the south and east of Iceland (Table 4). Due to the importance of agricultural activities (wool in particular) for the Icelandic economy, these results should be taken into account in order to improve preparedness and reduce impacts on the national socioeconomic system. Finally, results of the accessibility analysis (Figs. 3, 5) help the identification of zones with limited access to critical infrastructure by classifying the population in terms of travel time to strategic features (hospitals, police/fire stations and potential shelters). This analysis accounts for the travel speed of the road network, where pixels outside the road network are only allowed an average walking speed. Note that unlike agent-based strategies, the resulting model is time-independent and does not attempt to account for dynamic travel time costs due to route capacity or road congestion (Wood and Schmidtlein, 2012). However, least-cost-distance models still provide key information for preparedness and planning by identifying heterogeneities in the accessibility over the entire territory rather than modeling the behavior of individuals. A combined look at Figs. 1 and 3 highlights how most of the critical infrastructures are clustered around the main towns, with the main zone of low accessibility being the Vatnajökull area. Figure 5 is a combination of the analysis performed in Fig. 3 and the population census, and helps visualize the number of people as a function of the travel time to critical infrastructures. Figure $3 \mathrm{c}$ also shows that although uninhabited, Vestfjörour, the northwesternmost peninsula, has a low accessibility to police/fire stations. This is clearly reflected in Fig. 5, where a travel time greater than $3 \mathrm{~h}$ is associated with thousands of people. As a result, such a method is valuable to plan the implementation of additional critical infrastructures for future crises.

The analysis of impacts performed here is essentially qualitative. The underlying vulnerability assessment does not include a physical vulnerability analysis of the elements at stake, due to the limited availability of data at the scale of the analysis. The definition of critical ash load thresholds does not rely on fragility curves, instrument commonly recognized amongst the risk management community but having a very limited application to volcanology (ENSURE, WP 1 - Del. 1.1.1). In particular, fragility curves to tephra fallout are available for building typologies (associated with a given physical vulnerability), but are still not well characterized in the case of ash fallout on main infrastructures, for which there are many factors (composition, humidity) that play an important role (Wilson et al., 2011). In addition, ash load thresholds can vary with weather conditions. For example, wet tephra has a higher impact on electric components (Wardman et al., 2012) and enhances the effects of ash coverage on road traffic (Wilson et al., 2011). Wilson et al. (2009b) pointed out the seasonal character of vulnerability, an important factor for certain activities such as agriculture and farming that have a seasonal character (Johánnesson, 2010). For example, the same hazardous phenomenon could have higher impacts on crops during the sowing, growth and flowering phases, while less impacts are expected on unplowed fields. Adapting thresholds to seasonal and weather variation would support the definition of specific seasonal strategies. Finally, we adopted the same threshold for all eruptive scenarios, ignoring that impacts can depend on many factors such as ash grain size and composition (Wilson et al., 2009b). 
Even though we adopted different grain-size distributions for each eruptive scenario (Biass et al., 2014), no study exists on ash load threshold dependency on granulometry and composition. Identifying critical ash load thresholds with single values introduces limitations into the usage of results. But given that the main aim of this work is identifying the areas and features that are expected to be impacted, results can support detailed impact assessment analysis at specific areas, necessary in order to produce more reliable results. Nowadays there is a growing need for specific studies to be performed in order to define quantitative thresholds that produce physical damages of elements and, eventually, systemic impacts. In future, fragility curves would allow hazard intensity and probability of damage to be accounted for, and our impact assessment methodology would be developed accordingly.

\subsection{Vulnerability and impact assessment of European air traffic}

We have proposed a vulnerability assessment that identifies the elements (airports, routes and airspace sectors) likely to have major impacts on the European air traffic system in the case of tephra dispersal from eruption of an Icelandic volcano. London is recognized to be the core of the European aviation system, followed by Paris, Amsterdam and Frankfurt, according to the number of connections handled (Fig. 6). Our analysis has also identified the routes that have the highest socioeconomic relevance, constrained to central and northwestern Europe based on the outcome of the hazard assessment (Biass et al., 2014). The analysis emphasizes the role of minor connections that, despite being secondary at the European level, are strategic for national economies. For example, the analysis of air traffic at London and Keflavík airports showed that London-Dublin and ReykjavíkCopenhagen are very important routes (Figs. 7 and 8) and their disruption could affect national economies and those of their commercial partners. We also estimated vulnerability of FIRs (Fig. 9) based on traffic data from a peak day. This first-order estimation could be enhanced using air traffic data during a larger time interval to account for weekly/seasonal traffic variability. Moreover, other indicators for FIRs, for example accounting for the different types of flights (charter, commercial, business, cargo), could also be considered. Despite these methodological limitations, the identification of strategic airspace sectors is an important result itself given that current air traffic management procedures are based on airspace capacity (Cook, 2007).

The methodology proposed in this work is flexible enough to include new administrative boundaries and new procedures in the vulnerability assessment. This is important if, as expected, regulation changes occur. At a European level, new trends in air traffic management are driven by the Single European Sky Commission Project (SESAR, http://ec. europa.eu/transport/modes/air/sesar/), aimed at ensuring capacity and safety needs to European aviation. The SESAR program includes the constitution of functional airspace blocks (FABs), expected to be operative in the next few years, which would reduce airspace fragmentation and support integrated airspace management (Arroyo, 2008). In the case of ash-contaminated airspace, the new SESAR regulation framework could be included in the analysis to support the development of new centralized strategies. It has also been suggested that the short-term capacity of sectors may be negotiated in order to allow rerouting of flights to opened FIRs, thus improving the performance of the network. However, procedures to be adopted in the case of ash-contaminated airspace (e.g., the possibility of overflying ash clouds) are still under discussion. The idea that the airlines will be able to decide whether to fly or not in ash-contaminated airspace has been proposed by EUROCONTROL and implemented during the 2011 VOLCEX exercise, as described in the final report (ICAO, 2011). This new paradigm could be implemented in the EUR/NAT region by several stakeholders that, after the approval of a safety risk assessment (SRA; Bolić and Sivčev, 2011; EASA, 2012), would be able to decide whether to fly or not through ash-contaminated airspace sectors. The introduction of SRA underlines the importance of having a long-term perspective in risk-management procedures and plans. Long-term risk management plans could also avoid secondary impacts, e.g., the lack of fleet at noncontaminated areas during the closure of main airports. For example, Icelandair managed to move aircraft from Keflavík to a secondary hub in the UK (Ulfarsson and Unger, 2011) to maintain operations in non-contaminated areas (and, in particular, intercontinental routes). Long-term hazard assessment and vulnerability and impact analysis can therefore support SRAs and mitigation measures and enhance the response in the case of volcanic ash contaminated airspace. It is worth noting that there is still no agreement on critical ash concentration thresholds or any other method (retrievals, measurements, ingestion rate) that may be used to characterize critical conditions for aircraft. This poses a high limitation to the application of impact assessment methodologies such as the one presented here. Further work should support the definition of thresholds and fragility functions in order to increase reliability of results.

In this work, we have proposed several ways of estimating impacts on the air traffic system, and our results give a wide perspective of the spatial and temporal magnitude of impacts. According to Fig. 11, all eruptive scenarios produce impacts in the London area, but the Askja OES 1875-type and Katla LLERS scenarios can result in major impacts for the whole European air traffic system. Low-magnitude, short-duration activity such as a 2000-type Hekla ERS does not result in high impacts on central European air traffic, but can disrupt relevant connections for the national economies involved (i.e., Reykjavík-Copenhagen, London-Dublin). The probability of having hazardous mass concentrations for more than $12 \mathrm{~h}$ (Biass et al., 2014) shows that high-magnitude scenarios such as the 1875-type Askja OES event can cause major 
disruptions ( $>1 \%$ probability) to London air traffic. Also, lower-magnitude but long-lasting activity such as a Katla LLERS scenario has $\mathrm{a}>1$ and $>5 \%$ probability of producing $12 \mathrm{~h}$ lasting disruption to London and Scotland, respectively, where the important airports of Glasgow and Edinburgh could be affected. Tables 6 and 7 show expected disruptions to Keflavík and London airports, based on averaged data. Note that this first-level impact assessment does not take into account the hour of the day and/or the day of the year in which a disruption occurs, which neglects differences between peak and off-peak (night and early morning) times. Average persistence times give information on the expected duration of disruptions, but given that the standard deviation for persistence time is on the order of 5-10 h (Biass et al., 2014), a high uncertainty is associated with these values. Nevertheless, this analysis allows for estimation on the order of magnitude of expected impacts and may support the definition of an "acceptable risk" based on averaged long-term values, which could eventually support a practical framework for risk management. Finally, average arrival time maps identify which airports and areas may need response plans and gives an idea of how much time is available for operations such as moving aircraft into hangars or part of the fleet to other airports. In fact, Guffanti et al. (2010) have shown how most damaging incidents during the last 60 years occurred within the first $1000 \mathrm{~km}$ from source volcanoes and within the first $24 \mathrm{~h}$ after eruption onset. The results of this impact assessment may therefore support the definition of strategies for many stakeholders involved in air traffic management during volcanic eruptions.

We also estimated impacts on FIRs (Fig. 11), accounting for the presence of ash at all FLs. The same impact analysis has been performed at specific FLs (Supplement Fig. S3), leading to significantly different results. In fact, impacts at a given FL strongly depend on the range of column heights of each eruption scenario, which in turn influences the probability of having ash at different FLs. For example, the Hekla ERS 2000-type scenario does not cause impacts at FL300 but only at lower levels. Consequently, a long-term impact assessment based on FL300 underestimates the expected impacts of low-magnitude eruptions such as the 2000- and 1947-type Hekla ERS scenarios. Analogously, impact assessment at airports (Tables 6 and 7) could be done considering all FLs or restricted at FL050, where most takeoff and landing operations take place. Given that air traffic management is based on the capacity of airspace sectors and these include several FLs (Cook, 2007), the second option seems more useful for decision making. For these reasons, we encourage the use of expected impact maps at FIRs, which are comprehensive of all FLs and provide a synthetic, conservative and meaningful support for the development of an SRA and other risk management plans.

Finally, this work has estimated the socioeconomic vulnerability of Europe to air traffic disruptions. The 2010 eruption of Eyjafjallajökull demonstrated that impacts at strategic airports such as London produce major systemic impacts on the rest of the European air traffic network and indirect socioeconomic impacts at a global scale (Oxford Economics, 2010). One example is the interruption of Kenyan exports to the UK (BBC News, 2010), which caused an economic impact on Kenyan agricultural sectors (Alexander, 2013). Here we did not describe such interactions but instead proposed a methodology to compare different sources of information that quantify the dependency of European areas on air traffic. The combination of demographic, trade and accessibility information (Supplement Fig. S3) identifies NUTS-2 regions with higher dependency on air traffic (Fig. 10), i.e., those more vulnerable to air traffic network disruptions. Moreover, the comparison of vulnerability maps for NUTS-2 regions and impact assessment results (Fig. 11 and Tables 6 and 7) identifies the most impacted areas from explosive eruptions in Iceland. For example, Ireland has a high vulnerability because it is an island (which inherently has a low multi-modal accessibility) and has strong social and commercial relationships with the UK, resulting in high socioeconomic impacts in the event of air traffic disruption. Also, Nordic countries such as Denmark and Norway are likely to be affected, in particular those regions with lower multi-modal accessibility. Flexibility of the transportation system and multi-modal accessibility are in fact critical factors that strongly influence the societal response to air traffic disruptions (Alexander, 2013). Moreover, a strategy that allows taking advantage of all different transportation means can strongly reduce losses during emergencies, as shown by Jones and Bolivar (2011) for the case study of Malta during the 2010 aviation disruption. Finally, civil aviation disruption is not only a problem for private stakeholders - it affects all of society, requiring procedures to mitigate the socioeconomic risk (Vainikka, 2010). Results of the vulnerability and impact assessment performed at the European level can support a socioeconomic impact analysis and the development of risk management plans. Data from European projects such as Eurostat, ESPON and TRACC are extremely relevant to support this analysis.

\subsection{Caveats}

First, the main aim of this work is identifying the areas that are expected to suffer impacts in the event of the selected scenarios occurring, at both the national and European scale. Given the difficulty in gathering specific data, our analysis does not account for physical vulnerability of most features. Thus, our simplified approach does not include an analysis of spatial inter- and intra-dependencies and cascading effects, as it relies on the characterization of physical vulnerability, which is beyond the scope of this work. The systemic aspects is covered only partially, by identifying specific elements and infrastructures that are important to the system performance on an a priori basis and assessing their expected impacts. This limitation is particularly important with regards to road 
and electricity network disruptions, whose failure may cause the disruption of dependent services and infrastructures and eventually lower the capacity of response of areas. Studies on electricity infrastructure vulnerability suggest that this analysis should start identifying where, how often, and for how long the electricity supply will be interrupted. This analysis should be performed by splitting the network at specific delivery points, implying a detailed knowledge of its structure (Kjølle et al., 2011). In order to be realistic and produce usable results, this kind of analysis requires therefore a collaboration between involved stakeholders (infrastructure holders, service providers and end users). The same conclusion can be drawn at the European scale, where interdependencies between elements are closely related to specific management plans of stakeholders involved (airlines, service providers). Thus, our work poses the basis for a specific analysis of these interdependencies by performing the first vulnerability and impact assessment for tephra fallout and dispersal in Iceland and Europe, and pointing out this issue to the stakeholders involved in territorial planning and longterm risk management. Second, the methodology proposed here is focused on a specific hazard caused by explosive volcanic eruptions (i.e., volcanic ash fallout and dispersal). But, given that there are other hazards at both scales that potentially affect the exposed targets, outcomes of our vulnerability and impact assessment could support multi-risk initiatives and be interfaced with specific analyses. For these reasons, we base our methodology on an integrated framework for vulnerability assessment proposed within the European project ENSURE (Menoni et al., 2012). At the European scale, this work may contribute to a multi-risk assessment including other hazards for aviation, such as volcanogenic $\mathrm{SO}_{2}$ or mineral dust. At the national scale, volcanic eruptions are the hazardous phenomenon that poses the higher threat to societies by means of many hazardous phenomena such as lava flow and jökulhaups (glacial outburst floods). In particular, in 1996 and 2011, jökulhaups in southern Iceland destroyed parts of Route 1 (main Ring Road) and two bridges. It is worth noting that these events usually happen at the very local scale, while ash fallout and dispersal have a wider spatial range. For these events to be analyzed in a multi-risk framework, eruptive scenarios should be modified and/or complemented in order to include these events. Further work is therefore required in this field and may enhance the integration of our results in a multi-risk framework.

\section{Conclusions}

This work represents the first example of a strategy that can be applied to various volcanic settings for the multi-scale impact assessment for tephra dispersal and deposition. The outcomes of such a strategy are designed to support decision making at both the national and the European scale. In particular, impact maps could improve preparedness and help develop risk mitigation actions in Iceland and support longterm risk management plans of companies that operate in the European airspace (e.g., SRA). Based on our analysis of the economic system at the national level and of critical airports, FIRs and air traffic routes at the European scale, we can draw the following conclusions:

At the national scale:

- In the case of an 1875-type OES occurring at Askja, the electricity network has a $10 \%$ probability of being impacted for $700 \mathrm{~km}$. The occurrence of LLERS at Katla and a 1947-type ERS at Hekla have a $10 \%$ probability of impacting more than $250 \mathrm{~km}$ of the national electricity network. Finally, the occurrence of a 2010-type LLOES at Eyjafjallajökull has a $10 \%$ probability of disrupting $122 \mathrm{~km}$ of the electricity network.

- In the case of a 1947-type ERS occurring at Hekla, five power plants have a $10 \%$ probability of being affected by ash fallout. If selected scenarios at Askja or Katla were to happen, four power plants would have a $10 \%$ probability of being affected by ash fallout, while other eruptive scenarios (2000 type at Hekla and 2010 type at Eyjafjallajökull have a low, but not null, probability of having impacts on power plants.

- In the case of any of the selected eruptive scenarios occurring, $1-10 \mathrm{~km}^{2}$ of Icelandic croplands have a $10 \%$ probability of being affected by ash fallout. Occurrence of eruptive scenarios at Askja and Katla have a $10 \%$ probability of affecting 287 and $125 \mathrm{~km}^{2}$ of pasture lands, respectively.

At the European scale:

- The occurrence of a 2000-type ERS at Hekla is likely to have very high impacts on the Reykjavík FIR (950 passengers stranded for at least $5 \mathrm{~h}$ ) and high impacts for the London FIR $(\sim 23000$ passengers stranded for at least $3 \mathrm{~h}$ ).

- The occurrence of a 1947-type ERS at Hekla is likely to have very high impacts on the Reykjavík FIR $(\sim 1500$ passengers stranded for at least $8 \mathrm{~h}$ ) and high impacts for the London FIR $(\sim 27000$ passengers stranded for at least $4 \mathrm{~h}$ ). The FIR of Paris, Brest and Marseille would also be strongly impacted.

- The occurrence of an 1875-type OES at Askja is likely to have very high impacts on the Reykjavík FIR ( 3600 passengers stranded for at least $18 \mathrm{~h}$ ) and high impacts for the London FIR ( 60000 passengers stranded for at least $8 \mathrm{~h}$ ). FIRs above France, Germany and Scandinavia would also be impacted.

- The occurrence of an LLERS scenario at Katla is likely to have a very high impact on the Reykjavík FIR ( 4300 passengers stranded for at least $21 \mathrm{~h}$ ) and 
high impact for the London FIR ( 78000 passengers stranded for at least $10 \mathrm{~h}$ ). It is also likely that FIRs above France, Germany and Scandinavia would be strongly impacted.

\section{The Supplement related to this article is available online at doi:10.5194/nhess-14-2289-2014-supplement.}

Acknowledgements. This work has been funded by the Spanish research project "Atmospheric transport models and massive parallelism: applications to volcanic ash clouds and dispersion of pollutants at an urban micro-scale" (ATMOST, CGL2009-10244) and the Fonds National Suisse project "Volcanic-Ash Dispersal from Selected Icelandic Volcanoes: Risk Assessment for the European Region" (IZK0Z2_142343). S. Biass is supported by SNF (\#200021-129997) and ESF/MemoVolc (\#5193) subsidies. Simulations have been done at the Section of Earth and Environmental Sciences, University of Geneva, and at the Barcelona Supercomputing Center (BSC-CNS), using the MareNostrum supercomputer. We thank the EUROCONTROL Network Management department for providing data and for their suggestions. Thanks to Árni Ragnarsson (Icelandic Regional Development Institute), Torfi Jóhannesson (University of Iceland, Department of Agricultural Sciences) for data on agricultural production, and to Landmælingar Islands for providing the local GIS database. We acknowledge the ESPON European project for the accessibility data.

Edited by: A. Costa

Reviewed by: two anonymous referees

\section{References}

Alexander, D.: Volcanic ash in the atmosphere and risks for civil aviation: a study in European crisis management, Int. J. Disaster Risk Sci., 4, 9-19, doi:10.1007/s13753-013-0003-0, 2013.

Arroyo, A.: Single European Sky and Functional Airpsace Blocks, Air Transport Directorate of the European Community, presentation given at Montreal, 2 June 2008, available at: www.icao.int/safety/information-management/ TransitionLibraryforAIM/Documentation/

SingleEuropeanSkyandFunctionalAirspaceBlocks.pdf (last access: September 2012), 2008.

Baxter, P. J., Ing, R., Falk, H., and Plikaytis, B.: Mount St. Helens eruptions: the acute respiratory effects of volcanic ash in a North American community, Arch. Environ. Health, 38, 138143, 1983.

BBC News: Volcanic flight ban hits Kenya farm workers, 20 April 2010, available at: http://news.bbc.co.uk/2/hi/8629079.stm (last access: September 2012), 2010.

Beccuti, M., Chiaradonna, S., Di Giandomenico, F., Donatelli, S., Dondossola, G., and Franceschinis, G.: Quantification of dependencies between electrical and information infrastructures, Int. J. Critical Infrastructure Protection (IJCIS), 5, 14-27, 2012.
Bertolini, L., Le Clercq, F., and Kapoen, L.: Sustainable accessibility: a conceptual framework to integrate transport and land use plan-making. Two test-applications in the Netherlands and a reflection on the way forward, Transp. Policy, 12, 207-220, 2005.

Biass, S., Frischknecht, C., and Bonadonna, C.: A fast GIS-based risk assessment for tephra fallout: the example of Cotopaxi volcano, Ecuador - Part II: vulnerability and risk assessment, Nat. Hazards, 64, 615-639, 2012.

Biass, S., Scaini, C., Bonadonna, C., Folch, A., Smith, K., and Höskuldsson, A.: A multi-scale risk assessment for tephra fallout and airborne concentration from multiple Icelandic volcanoes - Part 1: Hazard assessment, Nat. Hazards Earth Syst. Sci., 14, 2265-2287, doi:10.5194/nhess-14-2265-2014, 2014.

Birkmann, J. (Ed.): Measuring Vulnerability to Natural Hazards: Towards Disaster Resilient Societies, United Nation University Press, Tokyo, Japan, ISBN-10:92-808-1135-5, ISBN-13:978-92808-1135-3, 400 pp., 2006.

Birkmann, J.: Exposure to natural hazards, in: Encyclopedia of Natural Hazards, Encyclopedia of Earth Sciences Series, edited by: Bobrowsky, P. T., Springer-Verlag, Berlin Heidelberg, 305-306, 2013.

Bolić, T. and Sivčev, Ž.: Air Traffic Management in Volcanic Ash Events in Europe: a Year After Eyjafjallajökull Eruption, in: 94rd Transportation Research Board Annual Meeting, January 2011, Washington D.C., USA, 2011.

Bonadonna, C., Connor, C. B., Houghton, B. F., Connor, L., Byrne, M., Laing, A., and Hincks, T. K.: Probabilistic modeling of tephra dispersal: hazard assessment of a multiphase rhyolitic eruption at Tarawera, New Zealand, J. Geophys. Res., 110, B03203, doi:10.1029/2003JB002896, 2005.

Byggdastofnun: Icelandic regional development institute, available at: http://www.byggdastofnun.is/en/ (last access: September 2012), 2012.

CAA: Air traffic statistic database, available at: http://www.caa.co. uk/default.aspx?catid=2372 (last access: September 2012), 2012.

Ceudech, A., Deeming, H., Galderisi, A., Kallache, M., and Kropp, J.: From global to local and from local to global: examples of event scenarios in Europe, in: Inside Risk: a Strategy for Sustainable Risk Mitigation, edited by: Margottini, C. and Menoni, S., Springer-Verlag Italia, Milano, 249-286, 2011.

Cook, A. (Ed.): European Air Traffic Management: Principles, Practices and Reesearch, Ashgate Publishing, Ltd., London, UK, 2007.

Costa, A., Macedonio, G., and Folch, A.: A three-dimensional Eulerian model for transport and deposition of volcanic ashes, Earth Planet. Sc. Lett., 241, 3-4, 634-647, 2006.

Cutter, S.: Vulnerability, in: Encyclopedia of Natural Hazards, Encyclopedia of Earth Sciences Series, edited by: Bobrowsky, P. T., Springer-Verlag, Berlin Heidelberg, 2013.

Dawson, J., Delbos, E., Hough, R., Lumsdon, D., Mayes, B., and Watson, H.: Impacts of volcanic ash originating from the April 2010 eruption in Eyjafjallajokull (Iceland) on the natural resources of Scotland, The Mcaulay Land Use Research Institute, Aberdeen, 25 pp., 2010.

De la Cruz-Reyna, S. and Tilling, R. I.: Scientific and public responses to the ongoing volcanic crisis at Popocatépetl Volcano, Mexico: importance of an effective hazards-warning system, J. Volcanol. Geoth. Res., 170, 121-134, 2008. 
Dell' Olmo, P. and Lulli, G.: A new hierarchical architecture for Air Traffic Management: optimisation of airway capacity in a Free Flight scenario, Eur. J. Oper. Res., 144, 179-193, 2003.

Douglas, J.: Physical vulnerability modelling in natural hazard risk assessment, Nat. Hazards Earth Syst. Sci., 7, 283-288, doi:10.5194/nhess-7-283-2007, 2007.

Ensure, Del 2.1.2, Sapountzaki, K., Wassenhoven, L., Melissourgos, Y., Menoni, S., Kundak, S., Desramaut, N., Modaressi, H., Parker, D., Tapsell, S., Kropp, J., Costa, L., Kidron, G., Galderisi, A., and Profice, A.: Relation between systemic and physical vulnerability and relation between systemic, social, economic, institutional and territorial vulnerability, ENSURE project, WP2, deliverable 2.1.1, 93 pp., 2011.

EASA: Possible courses of action for EASA to address the issue of volcanic ash ingestion in turbine engines, European Aviation Safety Agency ${ }^{\circledR}$, available at: http://www.easa.europa.eu/rulemaking (last access: April 2013), 2012.

ESPON: Transport services and networks: territorial trends and basic supply of infrastructure for territorial cohesion, ESPON project Deliverable 1.2.1, 478 pp., 2004.

ESPON@: Espon publications database, available at: http://www. espon.eu/main/Menu_Publications/, last access: October 2013.

Esri: ArcGIS ${ }^{\circledR}$ software, available at: http://www.esri.com/ software/arcgis, last access: September 2012.

EUROCONTROL: Glossary for Flight Statistics \& Forecasts, Doc. Ref.: EUROCONTROL/STATFOR/Documents/87 Glossary, 41 pp., printed by EUROCONTROL Logistics and Support Services, Bureau GS.4, available at: http: //www.eurocontrol.int/sites/default/files/article/attachments/ eurocontrol-glossary-for-flight-statistics-and-forecasts.pdf (last access: September 2013), 2005.

EUROCONTROL: Number of Connections Between City Pairs in Europe, proprietary data, courtesy of Eurocontrol Network Management department, 2012.

European Commission press release: Aviation: Progress Reports Show Key Targets for European Air Traffic Management "at Risk", IP/11/1452, available at: http://europa.eu/rapid/ press-release_IP-11-1452_en.htm (last access: October 2013), 2011.

Eurostat: European statistical database, available at: http://epp.eurostat.ec.europa.eu/portal/page/portal/statistics/ search_database, last access: November 2013.

Folch, A., Costa, A., and Macedonio, G.: FALL3D: a computational model for transport and deposition of volcanic ash, Comput. Geosci., 35, 6, 1334-1342, 2009.

Frischknecht, C., Wagner, J. J., and Romerio, F.: Integrated risk analysis: how to consider coping capacity?, in: Risk Challengings Publics, Scientists and Governments, edited by: Menoni, S., CRC Press/Balkema, Leide, 105-177, 2010.

Fürst, F., Hackl, R., Holl, A., Kramar, H., Schurmann, C., Spiekermann, K., and Wegener, M.: "The SASI model: model implementation" - deliverable d11 of the EU project socio-economic and spatial impacts of transport infrastructure investments and transport system improvements (SASI), Berichte aus dem Institut für Raumplanung, IRPUD, Dortmund, 49 pp., 2000.
Galderisi, A. and Ceudech, A.: Mobility Network and Safety, TeMA Journal of Land Use, Mobility and Environment, Selected Papers 2009, 47-56, available at: http://www.tema.unina.it/index.php/tema (last access: October 2012), 2010.

Galderisi, A., Ceudech, A., and Pistucci, M.: A method for na-tech risk assessment as supporting tool for land use planning mitigation strategies, Nat. Hazards, 46, 221-241, doi:10.1007/s11069008-9224-8, 2008.

Galderisi, A., Bonadonna, C., Delmonaco, G., Ferrara, F. F., Menoni, S., Ceudech, A., Biass, S., Frischknecht, C., Manzella, I., Minucci, G., and Gregg, C.: Vulnerability Assessment and Risk Mitigation: The Case of Vulcano Island, Italy, Landslide Science and Practice, Vol. 7: Social and Economic Impact and Policies, Springer, Berlin Heidelberg, 55-64, doi:10.1007/978-3-642-31313-4_8, 2013.

GISCO: Geographical Information System of the European Commission, available at: http://epp.eurostat.ec.europa.eu/portal/ page/portal/gisco_Geographical_information_maps/geodata/ reference (last access: November 2012), 2013.

Gudmundsson, A., Oskarsson, N., Gronvold, K., Saemundsson, K., Sigurdsson, O., Stefansson, R., Gislason, S. R., Einarsson, P.,Brandsdottir, B., Larsen, G., Johannesson, H., and Thordarson, T.: The 1991 eruption of Hekla, Iceland, J. Volcanol. Geoth. Res., 54, 238-246, 1992.

Guffanti, M., Casadevall, T. J., and Budding, K.: Encounters of Aircraft with Volcanic Ash Clouds: A Compilation of Known Incidents, 1953-2009, US Geological Survey Data Series 545, Ver. 1.0, 12 pp., plus 4 appendixes including the compilation database, available at: http://pubs.usgs.gov/ds/545, 2010.

Gunnarsdóttir, M. J.: Safe drinking water: experience with water safety plans and assessment of risk factors in water supply, Ph.D. thesis, Faculty of Civil and Environmental Engineering, University of Iceland, Iceland, 128 pp., 2012.

Heathrow airport: Facts and figures, available at: http://www. heathrowairport.com/about-us/company-news-and-information/ company-information/facts-and-figures (last access: November 2013), 2013.

Hellstrom, T.: Critical infrastructure and systemic vulnerability: towards a planning network, Safety Sci., 45, 415-430, 2007.

Horwell, C. J. and Baxter, P. J.: The respiratory health hazards of volcanic ash: a review for volcanic risk mitigation, B. Volcanol., 69, 1-24, doi:10.1007/s00445-006-0052-y, 2006.

Höskuldsson, Á., Óskarsson, N., Pedersen, R., Grönvold, K., Vogfjörð, K., and Ólafsdóttir, R.: The millennium eruption of Hekla in February 2000, B. Volcanol., 70, 169-182, 2007.

ICAO: VOLCEX 2011 Final Exercise Report, available at: (last access: December 2012), 2011.

Icelandic National Energy Authority: On-line resources, available at: http://www.nea.is/hydro-power/electric-power/ hydro-power-plants/, last access: December 2012a.

Icelandic National Energy Authority: On-line resources, available at: http://www.nea.is/geothermal/electricity-generation/, last access: December 2012b.

Isavia air traffic statistics, available at: http://www.isavia.is/english/ about-isavia/statistics/ (last access: December 2013), 2012.

Jenks, G. F.: The data model concept in statistical mapping, Int. Yearbook Cartogr., 7, 186-190, 1967. 
Jóhannesdóttir, G. and Gísladóttir, G.: People living under threat of volcanic hazard in southern Iceland: vulnerability and risk perception, Nat. Hazards Earth Syst. Sci., 10, 407-420, doi:10.5194/nhess-10-407-2010, 2010.

Johánnesson, T.: Agriculture in Iceland: conditions and characteristics, the Agricultural University of Iceland, 32 pp., available at: http://eu.mfa.is/media/landbunadarmal/ Agriculture-in-Iceland-Conditions-and-Characteristics.pdf (last access: December 2012), 2010.

Jones, S. and Bolivar, E. M.: Natural Disasters and Business: The Impact of the Icelandic Volcano of April 2010 on European Logistics and Distribution - A case study of Malta, Maastricht School of Management, Working Paper No. 2011/20, 40 pp., 2011.

Jones, S. and Bolivar, E.: Natural Disasters and Business: The Impact of the Icelandic Volcano of April 2010 on European Logistics and Distribution - A case study of Malta, Maastricht School of Management, Working Paper No. 2011/20, 39 pp. available at: http://web2.msm.n1/RePEc/msm/wpaper/MSM-WP2011-20. pdf, last access: June 2014.

Keflavík International Airport: Facts and figures, available at: http://www.kefairport.is/English/Shortcuts/Statistics/ Facts-and-figures/ (last access: September 2012), 2011.

Keflavík International Airport: Statistics database, available at: http://www.kefairport.is/English/Shortcuts/Statistics/ (last access: September 2013), 2012.

Kjølle, G. H., Utne, I. B., and Gjerde, O.: Risk analysis of critical infrastructures emphasizing electricity supply and interdependencies, Reliabil. Eng. Syst. Safety, 105, 80-89, doi:10.1016/j.ress.2012.02.006, 2011.

Landmælingar Islands: National GIS data available at: http://www. lmi.is, last access: September 2012.

Landshagir: Statistical yearbook of Iceland, 2012, available at: http://www.statice.is/lisalib/getfile.aspx?itemid=14331 (last access: September 2013), 2012.

Laprie, J. C., Kanoun, K., and Kaâniche, M.: Modelling interdependencies between the electricity and information infrastructures, computer safety, reliability, and security, Lect. Notes Comput. Sci., 4680, 54-67, 2007.

Leal de Matos, P. and Powell, P. L.: Decision support for flight rerouting in Europe, Decis. Support Syst., 34, 397-412, 2002.

Leal de Matos, P. and Ormermod, R.: The application of operational research to European air traffic flow management - understanding the context, Eur. J. Oper. Res., 123, 125-144, 2000.

Menoni, S.: Costruire la Prevenzione, Pitagora Editrice, Bologna, 2005.

Menoni, S. and Margottini, C.: Inside Risk: a Strategy for Sustainable Risk Mitigation, Springer-Verlag Italia, 369 pp., 2011.

Menoni, S., Costa, L., Galderisi, A., and Margottini, C.: Deliverable 4.1 - methodological framework for an integrated multi-scale vulnerability and resilience assessment, ENSURE project, WP4, deliverable 4.1, 96 pp., 2011.

Menoni, S., Molinari, D., Parker, D., Ballio, F., Tapsell, S.: Assessing multifaceted vulnerability and resilience in order to design risk-mitigation strategies, Nat. Hazards 64, 2057-2082, doi:10.1007/s11069-012-0134-4, 2012.
Minciardi, R., Sacile, R., Taramasso, A. C., Trasforini, E., and Traverso, S.: Modeling the vulnerability of complex territorial systems: an application to hydrological risk, Environ. Modell. Softw., 21, 949-960, 2005.

Neteler, M., Bowman, M. H., Landa, M., and Metz, M.: GRASS GIS: a multi-purpose open source GIS, Environ. Modell. Softw., 31, 124-130, 2012.

Orkustofnun (National Energy Authority): Energy statistics in Iceland, available at: www.os.is/gogn/os-onnur-rit/orkutolur_ 2012-enska.pdf, last access: September 2012.

Oxford Economics: The Economic Impacts of Air Travel Restrictions Due to Volcanic Ash, Report for Airbus, available at: http://www.airbus.com/company/environment/documentation/ ?docID=10262\&eID=dam_frontend_push (last access: September 2012), 2010.

Parker, D. and Tapsell, S.: Relations between different types of social and economic vulnerability, Final draft report submitted to EU project "Enhancing resilience of communities and territories facing natural and na-tech hazards", ENSURE Deliverable 2.1, 89 pp., 2009.

Pascale, S., Sdao, F., and Sole, A.: A model for assessing the systemic vulnerability in landslide prone areas, Nat. Hazards Earth Syst. Sci., 10, 1575-1590, doi:10.5194/nhess-10-15752010, 2010.

Paton, D. and Johnston, D. (Eds.): Disaster Resilience, Charles, C. Thomas Publisher Ltd., Illinois, USA, 2006.

Pederson, P., Dudenhoeffer, D., Hartley, S., and Permann, M.: Critical Infrastructure Interdependency Modeling: A Survey of US and International Research, available at: www.inl. gov/technicalpublications/Documents/3489532.pdf (last access: September 2012), 2006.

PricewaterhouseCoopers: Economic Views: Future of World Trade, available at: http://www.economics.pwc.com (last access: September 2012), 2011.

Rashed, T. and Weeks, J.: Assessing vulnerability to earthquake hazards through spatial multicriteria analysis of urban areas, Int. J. Geogr. Informa. Sci., 17, 547-576, doi:10.1080/1365881031000114071, 2003.

Sammonds, P., McGuire, B., and Edwards, S.: Volcanic hazard from Iceland - analysis and implications of the Eyjafjallajokull eruption, UCL Institute for Risk and Disaster Reduction report, London, available at: http://www.ucl.ac.uk/rdr (last access: September 2012), 2010.

Statice: Statistics Iceland, available at: http://www.statice.is/, last access: September 2012.

Stewart, C., Johnston, D. M., Leonard, G. S., Horwell, C. J., Thordarson, T., and Cronin, S. J.: Contamination of water supplies by volcanic ash fall: a literature review and simple impact modelling, J. Volcanol. Geoth. Res., 158, 296-306, 2006.

Sulpizio, R, Folch, A., Costa, A., Scaini, C., and Dellino, P.: Hazard assessment of far-range volcanic ash dispersal from a violent Strombolian eruption at Somma-Vesuvius volcano, Naples, Italy: implications on civil aviation, B. Volcanol., 74, 2205-2218, doi:10.1007/s00445-012-0656-3, 2012. 
Tapsell, S,. McCarthy, S., Faulkner, H., and Alexander, M.: Social Vulnerability and Natural Hazards. CapHaz-Net WP4 Report, Flood Hazard Research Centre - FHRC, Middlesex University, London, available at: http://caphaz-net.org/outcomes-results/ CapHaz-Net_WP4_Social-Vulnerability2.pdf (last access: September 2012), 2010.

Thorarinsson, S. and Sigvaldason, G.: The Hekla eruption of 1970, B. Volcanol., 36, 269-288, 1971.

Thordarson, T. and Larsen, G.: Volcanism in Iceland in historical time: volcano types, eruption styles and eruptive history, J. Geodyn., 43, 118-152, doi:10.1016/j.jog.2006.09.005, 2006.

TRACC: Transport Accessibility at Regional/Local Scale and Patterns in Europe, Inception report, available at: http://www.espon. eu/main/Menu_Projects/Menu_AppliedResearch/tracc.html (last access: September 2013), 2010.

Ulfarsson, G. F. and Unger, E. A.: Impacts and Responses of Icelandic Aviation to the 2010 Eyjafjallajokull Volcanic Eruption, Transportation Research Record, J. Transport. Res. Board, 2214, 144-151, 2011.

UNISDR, United Nations International Strategy for Disaster Reduction Secretariat (UNISDR): Global Assessment Report on Disaster Risk Reduction, Geneva, Switzerland, 207 pp., ISBN/ISSN:9789211320282, available at: http://www. preventionweb.net/english/hyogo/gar/report/index.php?id=9413 (last access: September 2012), 2009.

Vainikka, J.: Plumes and paths: the Eyjafjallajokull eruption and airspace dependencies, Nordia Geographical Publications, 36, 3$14,2010$.
Wardman, J. B., Wilson, T. M., Bodger, P. S., Cole, J. W., and Stewart, C.: Potential impacts from tephra fall to electric power systems: a review and mitigation strategies, B. Volcanol., 74, 22212241, 2012.

Wegner, A. and Marsh, D.: A place to stand: airports in the European Air Network, EUROCONTROL Trends in Air Traffic Serie, 3, 74 pp., 2007.

Wilkinson, S. M., Dunn, S., and Ma, S.: The vulnerability of the European air traffic network to spatial hazards, Nat. Hazards, 60, 1027-1036, doi:10.1007/s11069-011-9885-6, 2001.

Wilson, T. M., Daly, M., and Johnston, D. M.: AELG 19 - Review of Impacts of Volcanic Ash Impacts to Electricity Distribution Systems, Broadcasting and Telecommunications, Auckland Regional Council Technical Publication No. 051., 79 pp., Auckland Engineering Lifelines Group, New Zealand, 2009a.

Wilson, T. M., Stewart, C., Cole, J. W., Dewar, D. J., Johnston, D. M., and Cronin, S. J.: The 1991 eruption of Volcán Hudson, Chile: Impacts on agriculture and rural communities and long-term recovery, GNS Science Report 2009/66, 100 pp., New Zealand, 2009b.

Wilson, T. M., Stewart, C., Sword-Daniels, V., Leonard, G., Johnston, D. M., Cole, J. W., Wardman, J., Wilson, G., and Barnard, S.: Volcanic ash impacts on critical infrastructure, Phys. Chem. Earth, 45-46, 5-23, 2011.

Wood, N. and Schmidtlein, M.: Anisotropic path modeling to assess pedestrian-evacuation potential from Cascadia-related tsunamis in the US Pacific Northwest, Nat. Hazards, 62, 275-300, 2012. 